\title{
A review on the genetic resources, domestication and breeding history of spinach (Spinacia oleracea L.)
}

\author{
Arnau Ribera • Yuling Bai • Anne-Marie A. Wolters • Rob van Treuren (1D) \\ Chris Kik
}

Received: 12 December 2019/Accepted: 20 February 2020/Published online: 27 February 2020

(C) The Author(s) 2020

\begin{abstract}
This paper addresses the genetic resources, domestication and breeding history of spinach as a comprehensive review of these crop aspects is currently unavailable. It is shown that the availability of genetic resources of wild relatives belonging to the primary gene pool is currently very limited, which hampers breeding and research activities. Therefore, new collecting expeditions are clearly warranted. The domestication of spinach is discussed on the basis of its presumed migration routes and the traits that were probably involved in the domestication syndrome. Spinach is thought to have domesticated in former Persia. Migration then occurred eastwards to China and westwards to Europe, but additional genetic data are needed to reveal the most likely migration routes. Morphological changes in pistillate flowers and loss of dormancy are identified as the main traits involved in the domestication syndrome of spinach. To a large extent we could re-construct the relationships between spinach cultivars that were developed until the 1950s, but this appeared difficult for the more recent cultivars due to intellectual property protection
\end{abstract}

A. Ribera · Y. Bai · A.-M. A. Wolters

Plant Breeding, Wageningen University and Research, P.O. Box 386, 6700 AJ Wageningen, The Netherlands

A. Ribera $\cdot$ R. van Treuren $(\bowtie) \cdot$ C. Kik

Centre for Genetic Resources, the Netherlands,

Wageningen Plant Research, P.O. Box 16, 6700 AA Wageningen, The Netherlands

e-mail: robbert.vantreuren@wur.nl by breeding companies. Resistance against downy mildew has been the main breeding target in spinach. The introgression of NBS-LRR resistance genes from wild relatives is the major strategy to develop downy mildew resistant cultivars. However, the use of lossof-function alleles of susceptibility genes may provide a more durable strategy to develop resistant cultivars. So far, abiotic resistance and quality traits have received minor attention in spinach research and breeding. This is expected to change considering the potential effects of climate change on these traits.

Keywords Breeding history - Crop wild relatives . Domestication $\cdot$ Plant breeding $\cdot$ Spinach

\section{Introduction}

Cultivated spinach (Spinacia oleracea L., $2 \mathrm{n}=2 \mathrm{x}=12$ ) is one of the most nutritious vegetables consumed worldwide (Morelock and Correll 2008). It is a leafy vegetable from the family Amaranthaceae, which includes other important crops such as beet, quinoa and amaranth (Hassler 2018). Spinach is an annual plant with distinct vegetative and reproductive phases. Typically, at the end of the winter or in early spring seeds are sown after which seedlings grow to form a rosette of leaves (Krarup and Moreira 1998; Van der Vossen 2004). The arrival of warmer and longer summer days induces bolting, hence 
spinach plants start their reproductive phase by growing a peduncle of about one metre tall (Krarup and Moreira 1998), generally with terminal staminate flowers and/or pistillate flowers at bract axils (Uotila 1997). Nowadays, many cultivars exist with distinct leaf attributes, from round to hastate leaves and from flat to crinkly (savoy) texture (Morelock and Correll 2008). Adaptation to different photoperiods and climatic conditions is also present, thus some cultivars possess bolting resistance to longer and warmer days to make them compatible with summer cultivation (Van der Vossen 2004).

Spinach is a wind-pollinated dioecious species, although monoecious plants also exist (Khattak et al. 2006). Spinach sex expression is flexible as different classes of spinach have been described based on sex and morphology (Rosa 1925). Some dioecious plants may show sex reversion resulting in gynomonoecy and andromonoecy, in the case of female and male plants respectively (Komai and Masuda 2004; Morelock and Correll 2008).

The global production of spinach reached more than 26.7 million tonnes in 2016, representing a production value of 18 billion USD (FAOSTAT 2018). Approximately $91.5 \%$ of this global spinach production is accounted for by China alone. Due to favourable environmental conditions, especially long daylength, spinach seed production is mainly based in Denmark (Morelock and Correll 2008; Deleuran 2010; Correll et al. 2011), covering more than $70 \%$ of the world's supply.

Spinach is rich in mineral elements and vitamins (Roberts and Moreau 2016), including substantial levels of the carotenoids vitamin A, lutein and zeaxanthin (Bunea et al. 2008) and other molecules with high antioxidant properties such as vitamin $\mathrm{C}$, vitamin $\mathrm{E}$ and phenolic compounds including flavonoids (Chun et al. 2005; Pandjaitan et al. 2005). Roberts and Moreau (2016) investigated the healthrelated effects of spinach, including studies of its antioxidant, anti-inflammatory, antitumoral, anti-obesity and lipid-lowering effects in animal models and humans. On the other hand, spinach is known for its high content in oxalic acid when compared to other crops (Mou 2008a). Oxalic acid can form insoluble salts with certain elements (Noonan and Savage 1999) and has been shown to reduce calcium, magnesium and zinc bioavailability in humans (Kelsay and Prather 1983; Heaney et al. 1988; Noonan and Savage 1999;
Bohn et al. 2004). Oxalic acid may also lead to the formation of kidney stones (Noonan and Savage 1999; Ermer et al. 2016). In addition to oxalic acid, spinach is also rich in nitrate (Santamaria 2006), which can be converted into nitrite in the digestive system (Tiso and Schechter 2015) and the latter can react with haemoglobin to form methaemoglobin, potentially causing methaemoglobinaemia (Santamaria 2006).

Despite the economical and nutritional importance of spinach, knowledge about the crop history is rather limited. Here we review the available publication sources regarding the related wild species, the domestication process and the breeding history of spinach. In addition, we summarize recent developments that are expected to open up a new era of spinach breeding.

\section{Wild relatives}

Currently, 11 species from the genus Blitum and two species from the genus Spinacia are considered to be part of the gene pool of cultivated spinach (Table 1; Vincent et al. 2013). While the Blitum species are classified in the tertiary gene pool, Spinacia tetrandra Steven ex M. Bieb and Spinacia turkestanica Iljin are assigned to the primary gene pool of cultivated spinach. Interestingly, Fujito et al. (2015) found that

Table 1 Wild species included in the spinach gene pool

Primary gene pool

Spinacia turkestanica Iljin

Spinacia tetrandra Steven ex M. Bieb

Tertiary gene pool ${ }^{\mathrm{a}}$

Blitum asiaticum (Fisch. \& C.A. Mey.) S. Fuentes et al.

Blitum atriplicinum F. Müll.

Blitum bonus-henricus (L.) Rchb.

Blitum californicum S. Wats.

Blitum capitatum $\mathrm{L}$.

Blitum hastatum Rydb.

Blitum korshinskyi Litv.

Blitum litwinowii (Paulsen) S. Fuentes et al.

Blitum nuttallianum Roem. \& Schult.

Blitum spathulatum (A. Gray) S. Fuentes et al.

Blitum virgatum $\mathrm{L}$.

${ }^{a}$ Blitum petiolare Link (Vincent et al. 2013) is also listed as a spinach wild relative, but the species is considered a synonym of Blitum capitatum L. (Hassler 2018) 
hybrids of $S$. oleracea $\times S$. tetrandra and $S$. tetran$d r a \times S$. oleracea showed a highly diminished pollen fertility, which might question the primary gene pool position of $S$. tetrandra. Additionally, recent studies (Fujito et al. 2015; Xu et al. 2017) indicated that $S$. oleracea is phylogenetically closer to $S$. turkestanica than to $S$. tetrandra, suggesting that $S$. turkestanica is the wild ancestor of cultivated spinach.

While S. turkestanica is autochthonous in Central and Southern Asia, S. tetrandra is autochthonous in the Middle East and Transcaucasia (Fig. 1; Hassler 2018). Collecting of wild spinach by local inhabitants was observed during collecting expeditions of the Centre for Genetic Resources, the Netherlands (CGN; Kik 2008). This seems to occur in parallel to the growing of cultivated spinach, although commercial cultivation was found to be rare in Armenia, Azerbaijan, Uzbekistan and Tajikistan, countries in which wild spinach is present (Van Treuren et al. 2019).

At the morphological level, S. turkestanica and $S$. tetrandra are very similar and both species resemble cultivated spinach to a large extent (Fig. 2). However, some differences between the species can be observed in the inflorescences. While $S$. turkestanica shows only cauline clusters of flowers in the inflorescences and short petioles in its bracts, $S$. tetrandra shows both cauline and basal clusters of flowers, and the bracts lack a petiole (Uotila 1997). Interestingly, Kik (unpublished data) observed bracts of $S$. tetrandra with petioles on basal positions but not on apical ones.

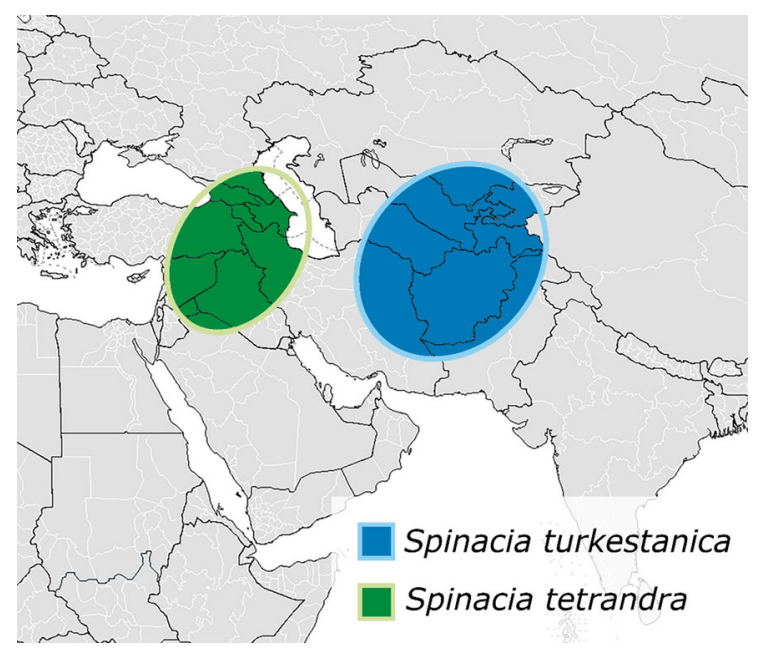

Fig. 1 Presumed distribution area of S. turkestanica (blue) and S. tetrandra (green). (Color figure online)
Furthermore, sexual dimorphism is more pronounced in S. tetrandra, as male plants are considerably smaller than females (Fig. 2).

Both S. turkestanica and S. tetrandra are of large interest to the breeding industry as they are used as source material for agronomically relevant traits, especially in case of resistance breeding against spinach downy mildew, caused by the oomycete Peronospora farinosa f. sp. spinaciae (Pfs), also referred to as Peronospora effusa (Greville) Rabenhorst (Correll et al. 1994; Qian et al. 2016). As new Pfs races appear continuously (Feng et al. 2018), breeders benefit from potential new resistance sources present in wild spinach germplasm.

Out of the nearly 2097 accessions of the genus Spinacia maintained in genetic resources collections worldwide 1959 are classified as S. oleracea, indicating the poor availability of wild spinach in gene banks (Table 2). In 2012, only 14 accessions of S. turkestanica and 12 of $S$. tetrandra were available in gene bank collections (Van Treuren et al. 2012). Due to this poor representation, CGN collected a total of 66 new accessions of S. turkestanica in 2008 and 36 new accessions of S. tetrandra in 2011 (Van Treuren et al. 2019). To date, 89 accessions of $S$. turkestanica and 49 accessions of $S$. tetrandra are included in genetic resources collections (Table 2), while an additional 10 accessions of $S$. tetrandra will become available by the end of 2020 (Van Treuren et al. 2019). Spinach collections could be further improved by introducing accessions from thus far unexplored regions, such as $S$. tetrandra from the Middle East and South-West Asia and S. turkestanica from South and South-West Asia. However, organising collecting expeditions on a legal basis has become increasingly difficult for many countries, not in the least due to more stricter requirements regarding access and benefit sharing.

\section{Domestication}

Geographical spread

Spinach is considered to have been domesticated first in the region of present Iran (Boswell 1949) and to have spread to other regions late in history (Fig. 3) as no evidence of the presence of the crop in the ancient Greek or Roman civilizations has been found (Heine 2018). The oldest available records indicate that 


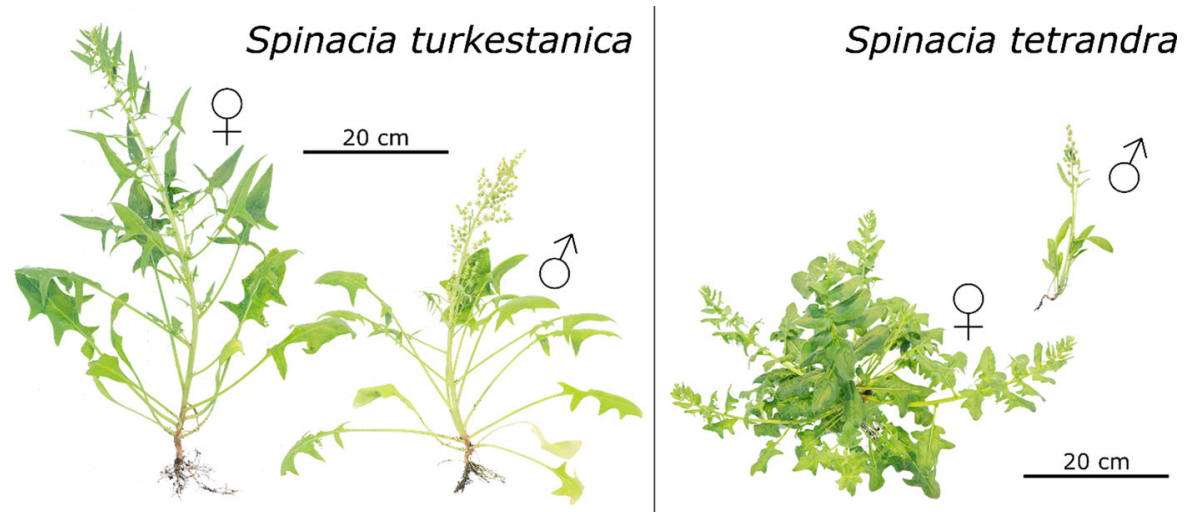

Fig. 2 Illustrations of both sexes of S. turkestanica and S. tetrandra

spinach was consumed in Mesopotamia in the 4th century AD (El Faïz 1995, as cited in Hallavant and Ruas 2014). The earliest written evidence of cultivated spinach is from China and dates back to the 7th century, showing that spinach arrived in China via Nepal (Laufer 1919). Even though Rolland and Sherman (2006) state that the Saracens introduced spinach to Sicily in the 9th century, the first written records mentioning cultivation around the Mediterranean region date back to the 10th century in Muslim territories (Sneep 1983) and the first written record in continental Europe dates back to the 12th century in Moorish Spain (El Faïz 2000). This latter document mentions spinach cultivation in the Iberian Peninsula since at least the 11th century. The first European archaeobotanical evidence was found in a French Pyrenean village and dates back to the end of the 12th or the beginning of the 13th century (Hallavant and Ruas 2014). Considering the proximity of this location to Spain, it seems plausible that spinach spread to Europe from the Iberian Peninsula, even though the migration routes throughout Europe are still unresolved (Hallavant and Ruas 2014).

The aforementioned historical evidence suggests that the spread of spinach followed two separate directions, one to Southern and Eastern Asia and another one to Africa, the Mediterranean and Northern Europe, from which it was later introduced in the Americas. A distinction is often made between two main groups of spinach cultivars, namely Asian-type and Western-type cultivars (Simoons 1990; Van der Vossen 2004), which have probably resulted from the different selection regimes applied in the two regions. Recent phylogenetic studies have shown an association between genetic relationship and geographical origin of spinach accessions, with consistent differences between Asian and Western cultivars (Shi et al. 2017; Xu et al. 2017). At the morphological level, Asian cultivars preserved the narrow, hastate and smooth leaf shape and the long petioles of wild spinach, whereas Western cultivars changed the hastate leaf shape to a round form, while leaves were enlarged and the savoy leaf texture appeared (Van der Vossen 2004).

\section{Domestication syndrome}

Domestication syndrome traits are not obvious in spinach because $S$. oleracea largely resembles both wild Spinacia species. According to Sneep (1983) the oldest available spinach descriptions and botanical drawings are from Leonard Fuchs (1543) and Hieronymus Bock $(1539,1546)$. Comparison of these drawings with a wild Spinacia plant clearly illustrates the similarity (Fig. 4). Therefore, leaf shape and plant morphology were probably not part of the domestication syndrome of spinach. Interestingly, wild spinach species are dioecious (Astley and Ford-Lloyd 1981) even though both Fuchs' (1543) and Bock's (1546) drawings depict monoecious plants. This raises the question whether monoecism was a potential domestication trait or not.

The main difference between cultivated spinach and wild Spinacia species is the morphology of the pistillate flowers. Wild species show clusters of fused flowers, which progress into spiny aggregated fruits containing multiple seeds (Fig. 5). Astley and FordLloyd (1981) suggested that having both sexes 
Table 2 Number of accessions of $S$. oleracea, $S$. turkestanica and $S$. tetrandra maintained in genetic resources collections

\begin{tabular}{|c|c|c|c|c|}
\hline Collection $^{\mathrm{a}}$ & S. oleracea & S. turkestanica & S. tetrandra & Total \\
\hline NLD037 & 408 & 75 & 29 & 512 \\
\hline USA020 & 340 & 8 & 6 & 354 \\
\hline DEU146 & 208 & 3 & 3 & 214 \\
\hline BGR001 & 204 & 0 & 0 & 204 \\
\hline TUR001 & 168 & 0 & 0 & 168 \\
\hline GBR006 & 122 & 2 & 1 & 125 \\
\hline HUN003 & 97 & 0 & 0 & 97 \\
\hline UKR008 & 84 & 0 & 0 & 84 \\
\hline ESP027 & 80 & 0 & 0 & 80 \\
\hline SWE054 & 80 & 0 & 0 & 80 \\
\hline ESP026 & 31 & 0 & 0 & 31 \\
\hline POL030 & 25 & 0 & 0 & 25 \\
\hline AUT046 & 23 & 0 & 0 & 23 \\
\hline AZE015 & 23 & 0 & 0 & 23 \\
\hline CZE122 & 17 & 0 & 0 & 17 \\
\hline CHE001 & 8 & 0 & 0 & 8 \\
\hline PRT001 & 7 & 0 & 0 & 7 \\
\hline UKR021 & 7 & 0 & 0 & 7 \\
\hline ARM035 & 0 & 0 & 5 & 5 \\
\hline AUT047 & 5 & 0 & 0 & 5 \\
\hline GRC005 & 4 & 0 & 0 & 4 \\
\hline MKD001 & 4 & 0 & 0 & 4 \\
\hline GBR004 & 0 & 1 & 2 & 3 \\
\hline GBR017 & 3 & 0 & 0 & 3 \\
\hline GEO013 & 3 & 0 & 0 & 3 \\
\hline ROM007 & 3 & 0 & 0 & 3 \\
\hline AZE014 & 0 & 0 & 2 & 2 \\
\hline BEL002 & 2 & 0 & 0 & 2 \\
\hline ARM002 & 0 & 0 & 1 & 1 \\
\hline ISR002 & 1 & 0 & 0 & 1 \\
\hline ITA363 & 1 & 0 & 0 & 1 \\
\hline ROM023 & 1 & 0 & 0 & 1 \\
\hline Total & 1959 & 89 & 49 & 2097 \\
\hline
\end{tabular}

enclosed in one single fruit is valuable in nature to avoid isolation of the sexes and ensure reproduction of dioecious plants. Cultivated spinach shows clusters of ununited flowers, resulting into separate round and slightly flattened fruits. As the presence of separate fruits may probably have eased the sowing and seed collecting tasks, this trait may have been selected to reduce manual labour and may have become fixed during the domestication of spinach.

The smooth fruit trait seems to have appeared in Europe at the end of the Middle Ages or at the beginning of the Modern History. In fact, the first written evidence of smooth fruits dates back to 1539 (Bock 1539), indicating that this trait was not part of the domestication syndrome of spinach. Multiple emergences of the smooth phenotype may have independently occurred as the presence or absence of prickles is controlled by a single gene, with spines being dominant over smoothness (Pandey and Kalloo 1993). The smooth phenotype has also been observed in landraces from the Middle East (Sabaghnia et al. 2014; Mohebodini et al. 2017). 


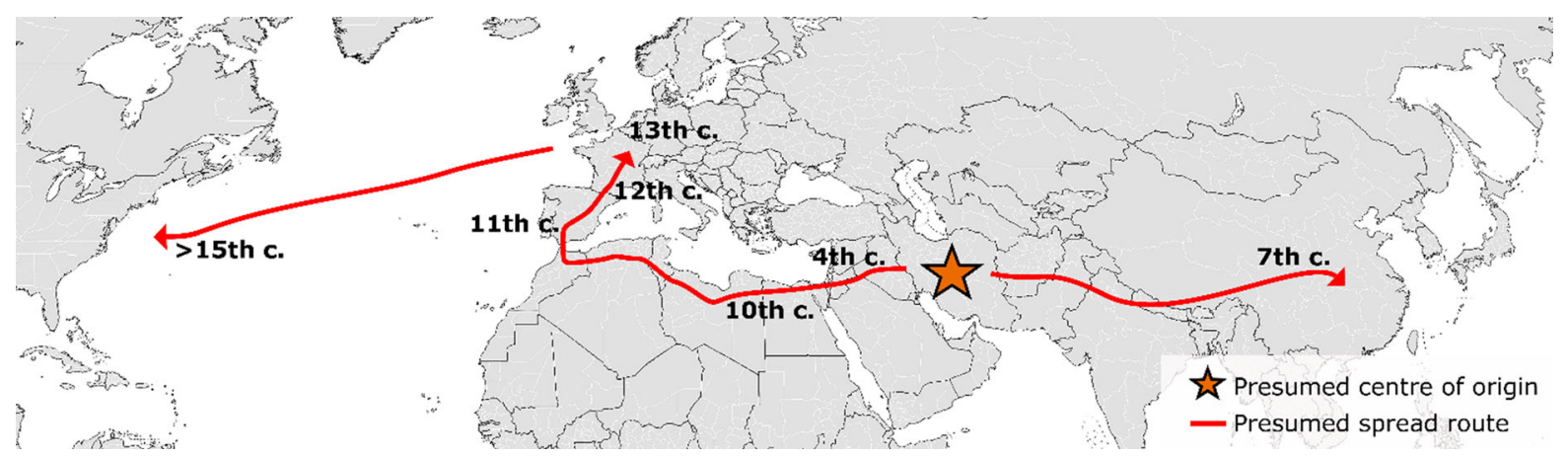

Fig. 3 Presumed centre of origin and migration routes of spinach. Timelines are indicated by century AD
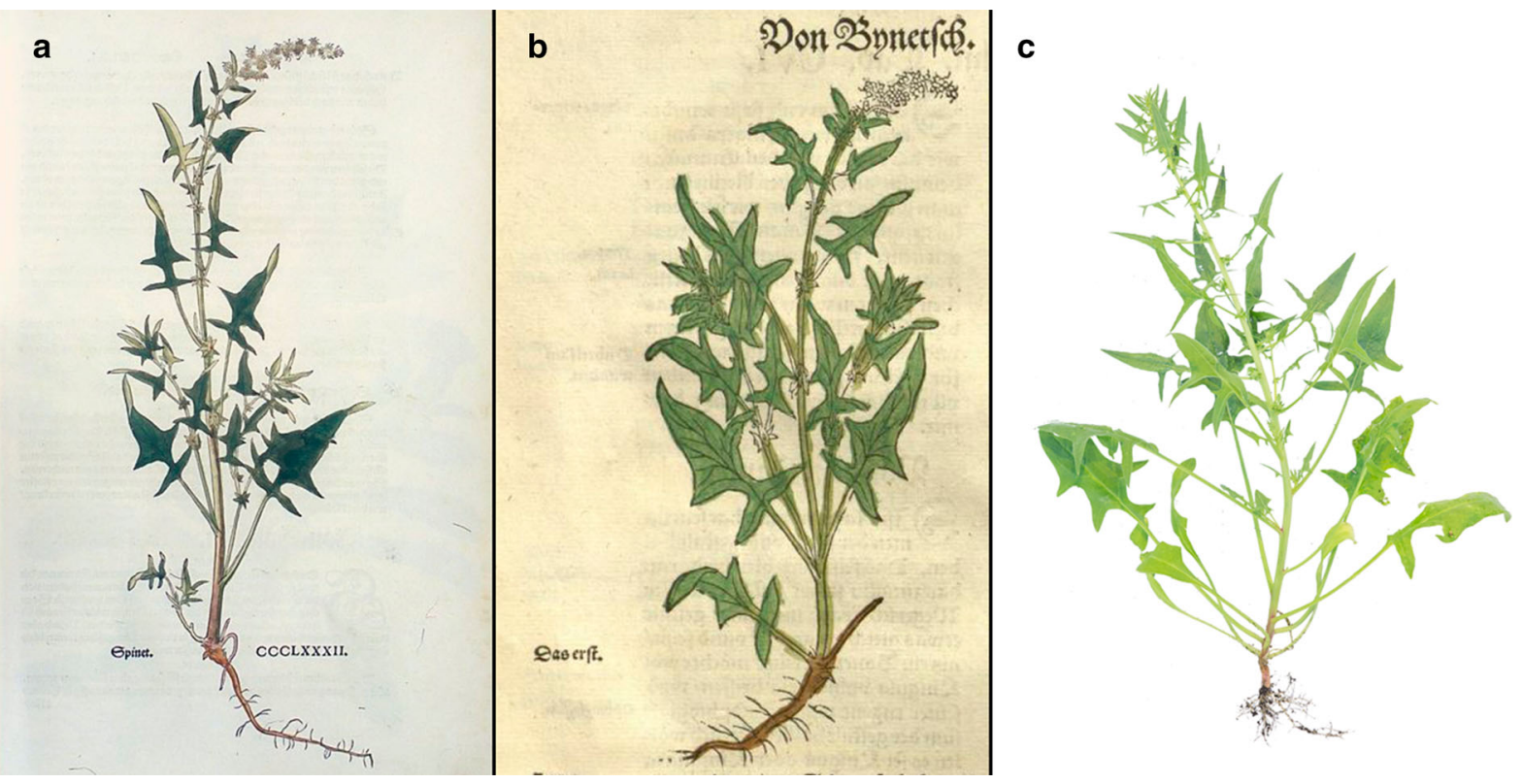

Fig. 4 First botanical drawings of $S$. oleracea $(\mathbf{a}-\mathbf{b})$, in both cases depicting monoecious plants. a Spinach drawing in the book New Kreüterbuch (Fuchs 1543, p. 668), b spinach drawing in the book Kreüter Buch (Bock 1546, p 277), c female plant of S. turkestanica

Seed dormancy was reduced during the domestication of spinach as germination is typically high in cultivated spinach but low in wild Spinacia (Van Treuren et al. 2019). Loss of dormancy is a common domestication trait and has been selected in parallel in multiple crop families (Rendón-Anaya and HerreraEstrella 2018; Wang et al. 2018a). Although dormancy is advantageous for plant survival in the wild by avoiding potentially unsuitable environmental conditions (Bentsink and Koornneef 2008), uniformity and reliability in germination are preferred for cultivation (Finch-Savage and Bassel 2016).

\section{Crop breeding}

Early breeding history

Studying how spinach looked like in previous times and how new cultivars arose is difficult due to scarce documentation. During the 1950s, Sneep collected evidence regarding the domestication and breeding history of spinach. A paper about his results was published in 1957 as a communication from the former IVT (Institute for Horticultural Plant Breeding, Wageningen, the Netherlands) and was subsequently translated into English and published in 1983. Sneep's paper is probably the best and most complete source 
a

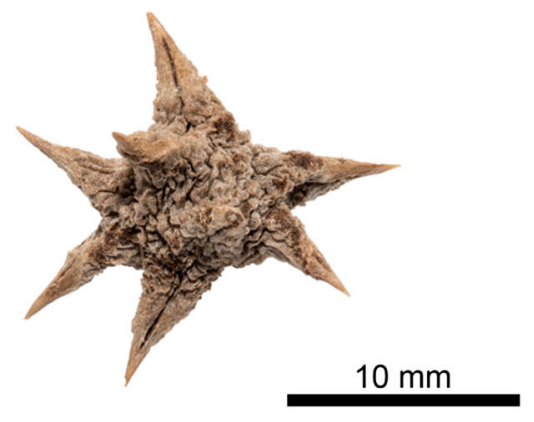

c
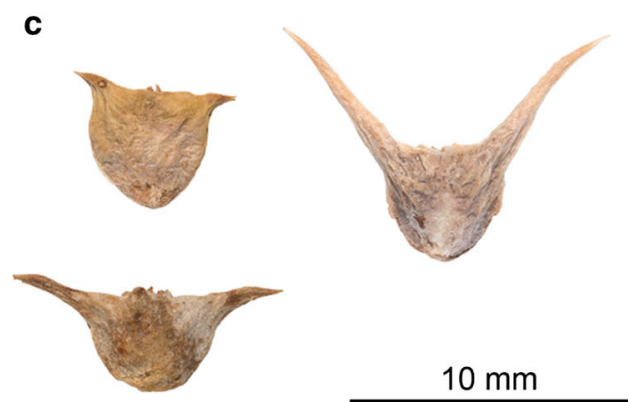

$10 \mathrm{~mm}$

e
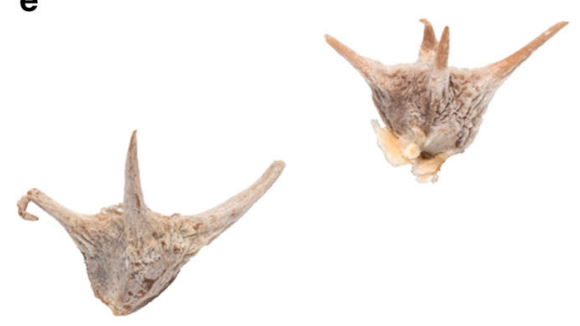

$10 \mathrm{~mm}$ b

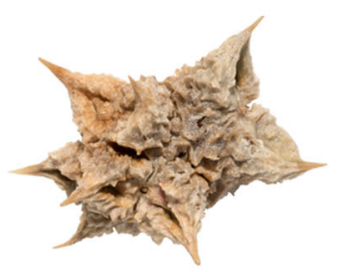

$10 \mathrm{~mm}$

d
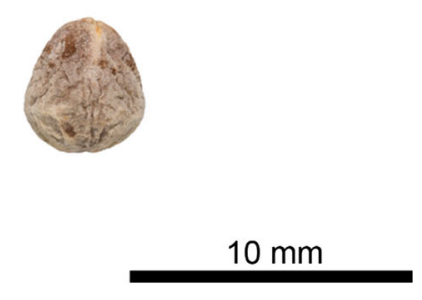

f

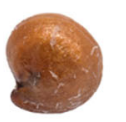

Fig. 5 Spinacia fruits and seed. a Aggregated fruit of $S$. turkestanica, b aggregated fruit of S. tetrandra, c typical spiny fruits of $S$. oleracea, $\mathbf{d}$ round fruit of $S$. oleracea, e atypical spiny fruits of $S$. oleracea, with three (left) and four (right) spines, $\mathbf{f}$ seed of $S$. oleracea

regarding the breeding history of spinach until the 1950s. The modern breeding history of spinach from 1950 onwards is difficult to reveal as breeding companies usually keep their breeding information confidential. A summary of the main events in the breeding history of spinach is shown in Fig. 6.

Based on current knowledge, Bock (1539) was the first author to differentiate between two spinach cultivars. While one cultivar had spiny seeds and leaves with hastate shape, the other one showed smooth seeds and broader leaves with a less pronounced hastate shape (Bock 1539; Sneep 1983). Evidence of additional spinach cultivars was absent from the literature until publication of the books
'Paradisi in Sole Paradisus Terrestris' in 1629 (Parkinson 1904) and 'The Gardeners Dictionary' (Miller 1731, 1768).

Around the 19th century more information concerning spinach and many other crops became available (Sneep 1983). This was due to the fact that breeding companies and seed merchants started to denominate cultivars and to add a brief description to these products, indicating their qualities and marketable traits. The French seed company VilmorinAndrieux started to play a major role in spinach breeding during the 19th century, and important information can be extracted from this company's pricelists, starting as early as 1771 (Vilmorin- 
MILESTONES

Hastate, pointy and small leaves

Quick-bolting

Spiny seeds
Round, big leaves

Slow-bolting

Smooth seeds

1955

USDA releases the first

Pfs and CMV resistant

hybrid: "Early Hybrid 7"

"Épinard de Hollande" are

the two most relevant cultivars

1629

First reference to a third spinach cultivar (spiny)

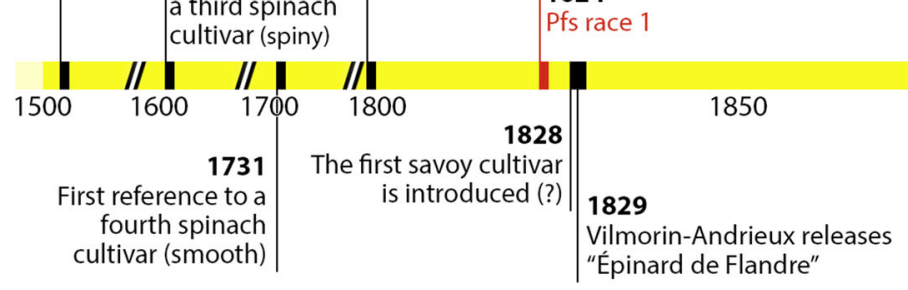

fourth spinach
cultivar (smooth)

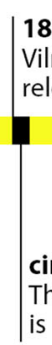

1873

Vilmorin-Andrieux releases "Viroflay"

Ernst Benary introduces the first hybrid spinach

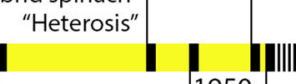

The first savoy cultivar is introduced (?)

USDA introduces the Pfs and CMV resistant hybrid "Dixie Market" and a Viroflay with introgressed Pfs resistance named "Califlay"

\section{MILESTONES}

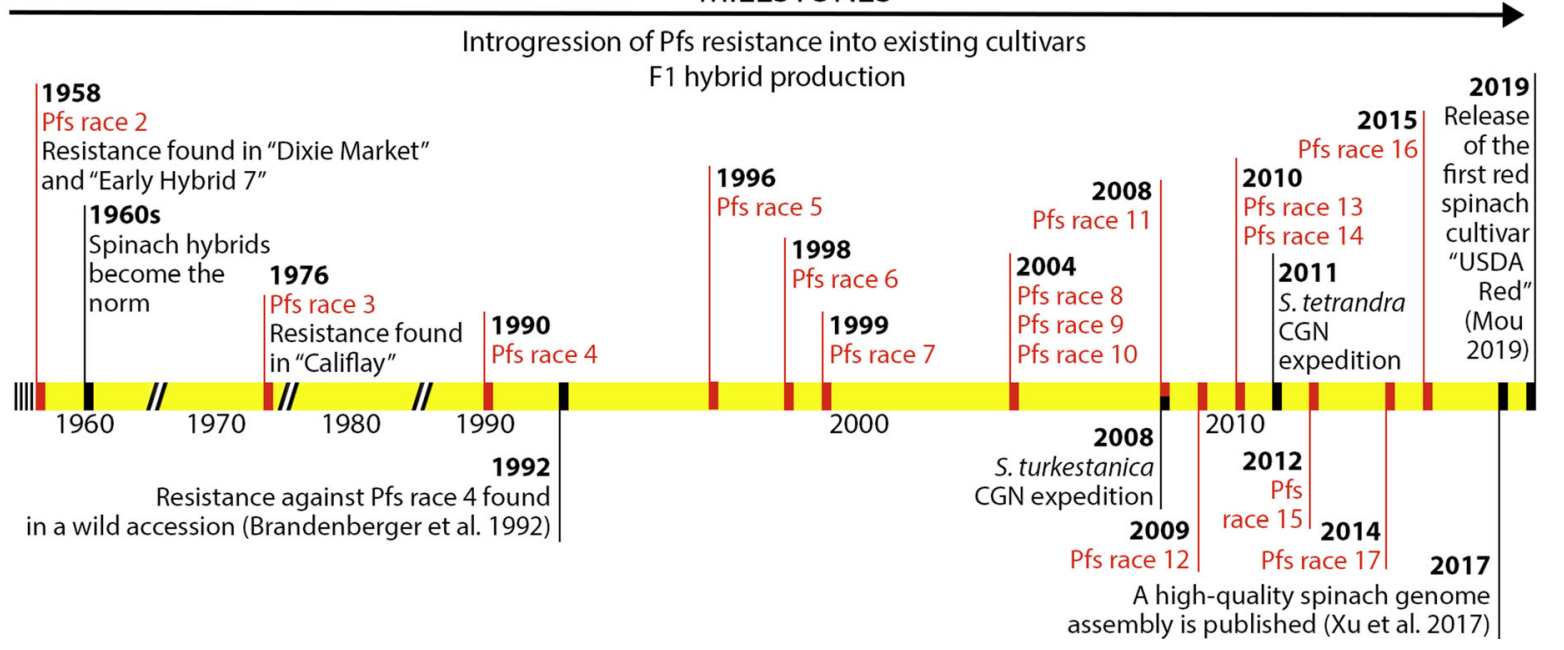

Fig. 6 Summary of the breeding history of spinach. The years in which new downy mildew (Pfs) races were observed are marked in red colour

Andrieux 1855, 1883; Sneep 1983). Gibault (1912) and Sneep (1983) considered that some of VilmorinAndrieux's cultivars represented the precursors of European cultivars. Gibault emphasized that Vilmorin-Andrieux's cultivars 'Épinard d'Angleterre' and 'Épinard de Hollande' became the two most relevant cultivars by the end of the 18th century, the former being a prickly-seeded and the latter a smoothseeded cultivar. From 'Épinard de Hollande' Vilmorin-Andrieux produced the cultivar 'Épinard de Flandre' in 1829 (Gibault 1912), referred to as
'Vlaamse' in the Netherlands (Sneep 1983), which was described as the most common cultivar at that time (Vilmorin-Andrieux 1883).

Since the end of the 19th century, Dutch breeders have played a leading role in spinach breeding (Sneep 1983). In particular, the role of Sluis \& Groot (currently part of Syngenta) and Rijk Zwaan has been significant in the breeding history of spinach.

Different improved cultivars were selected from 'Épinard d'Angleterre', 'Épinard de Hollande' and 'Épinard de Flandre' (Fig. 7). These selections 


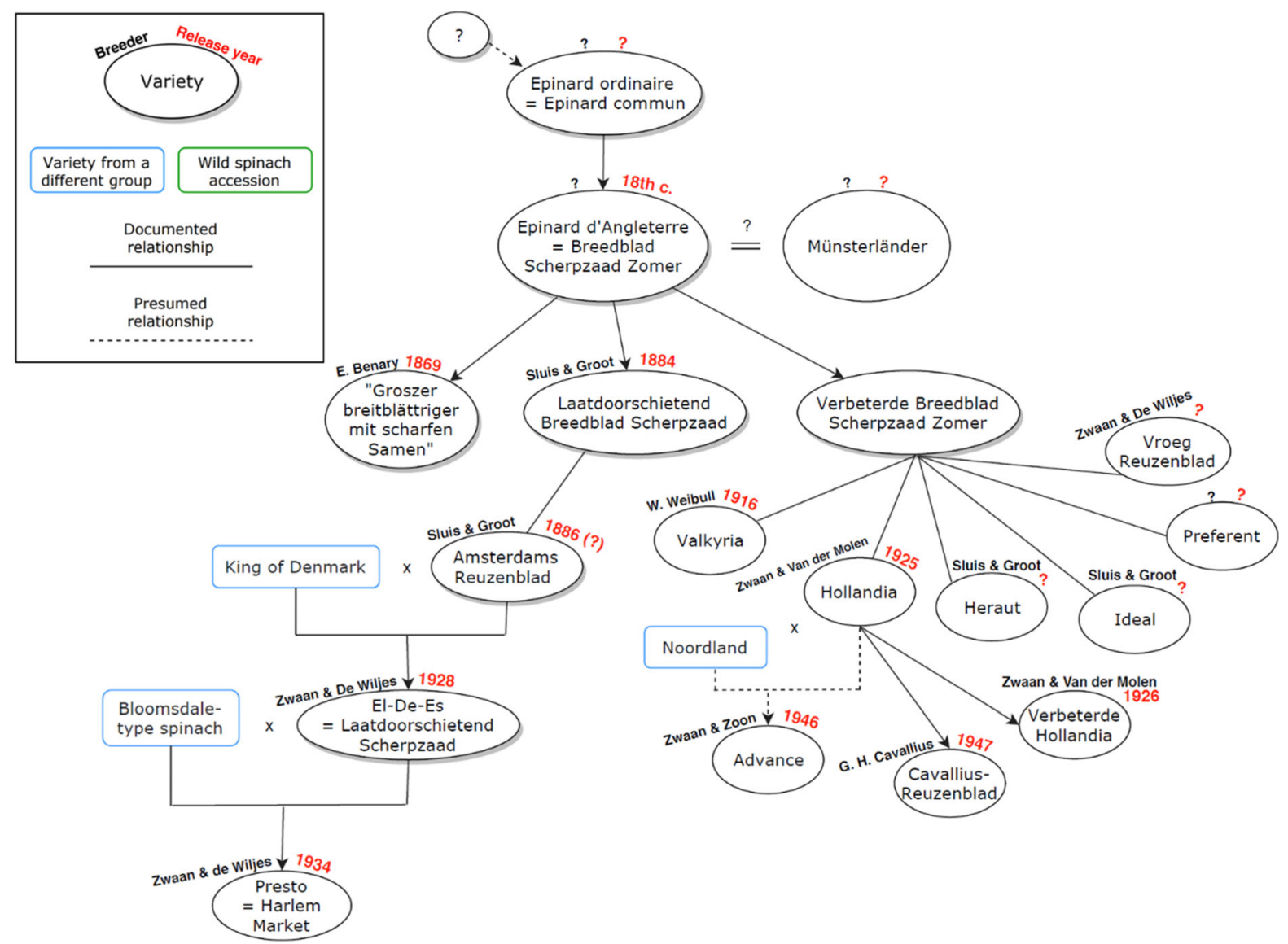

Fig. 7 Breeding history and ancestry of spiny-seeded spinach

showed the improved characteristics in response to the main breeding targets of spinach selection until the mid-20th century, namely larger, fleshier and darker green leaves with a rounder shape and a reduced tendency to bolt. Moreover, many cultivars were selected against leafless males, resulting in new cultivars that were mostly female or monoecious (Sneep 1983). Even though spiny-seeded cultivars were diversified, and new selections appeared during the 20th century (Fig. 7), the general trend was to breed for smooth-seeded rather than for spiny-seeded cultivars.

Supposedly, smooth-leaved cultivars were mainly derived from two selections of 'Épinard de Flandre', namely 'Gaudry' and 'Monstrueux de Viroflay', or simply 'Viroflay' (Fig. 8). 'Gaudry' was released in 1843 and 'Viroflay' was commercialized for the first time in 1873 by Vilmorin-Andrieux. Both 'Gaudry' and 'Viroflay' served as a source for many new selections and crossing programmes, which interestingly resulted in late-bolting summer cultivars, such as 'Nobel' in 1926 and 'Viking' in 1933, as well as winter-hardy cultivars, such as 'Géant d'Hiver' in 1927 (Sneep 1983).

Savoy-leaved cultivars, also called Bloomsdaletype spinach, followed a separate breeding history (Fig. 9). Due to their leaf shape, these were preferred over smooth-leaved cultivars in regions where vegetables needed transportation over long distances (Sneep 1983; Rubatzky and Yamaguchi 1997). Crinkles kept spinach less compact during packing and transport, resulting in an extended shelf life.

The initial savoy cultivar was called 'Savoyleaved', 'Norfolk' and 'Bloomsdale' later on (Fig. 9). The cultivar may have been derived from the 'Épinard de Flandre' or a similar cultivar (Kinney 1896), while also the year of introduction is not exactly known. The year of introduction may have 


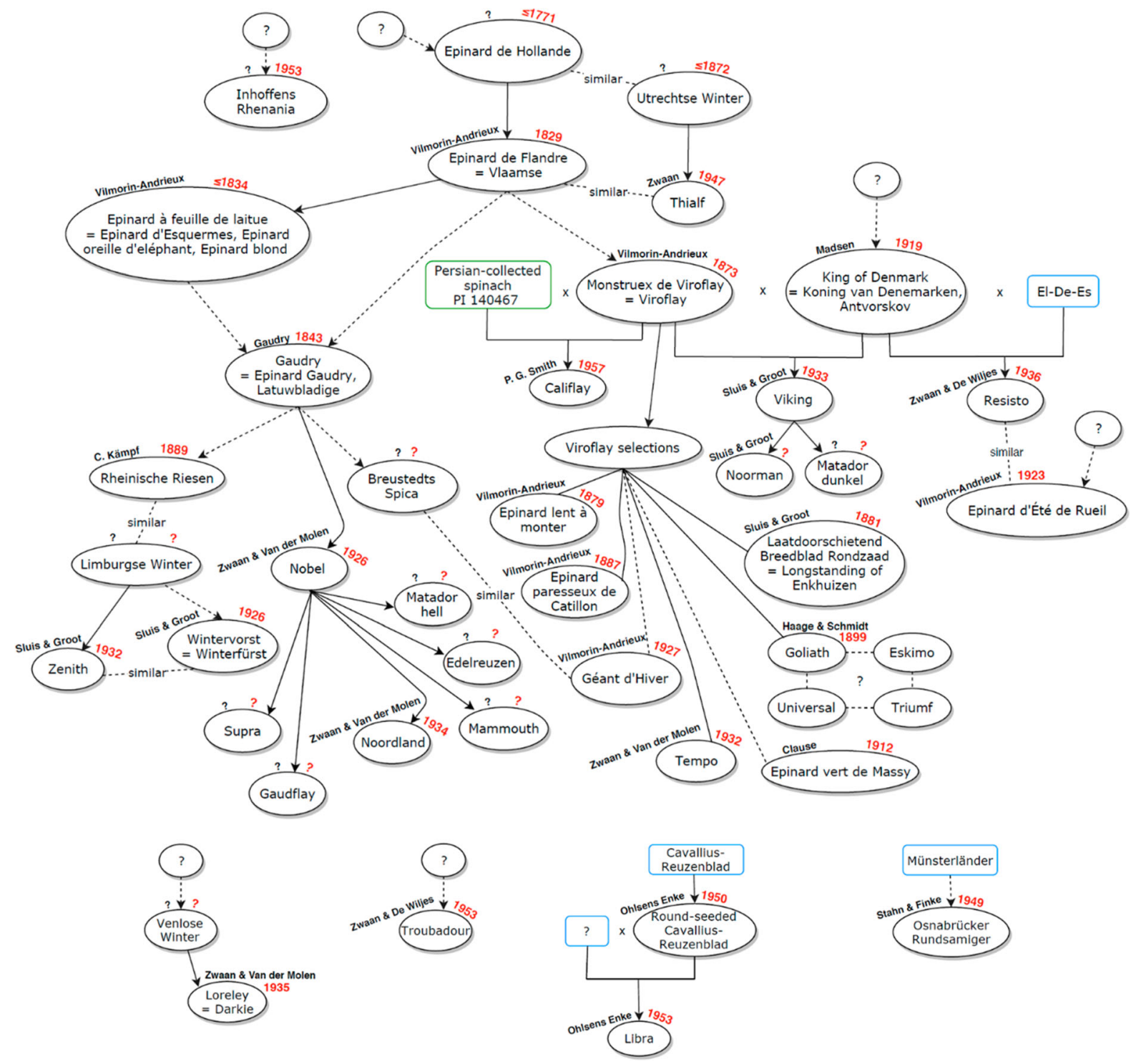

Fig. 8 Breeding history and ancestry of smooth-leaved, smooth-seeded spinach. See the box in Fig. 7 for explanation

been around 1874 (Kinney 1896; Sneep 1983) but in other sources 1828 is mentioned (Sneep 1983; Decoteau 2000). Several selections were made from 'Bloomsdale', improving the colour to dark-green and delaying the time to bolt.

Breeding for biotic stress tolerance

\section{Spinach blight}

In 1920, the spinach industry in the USA was threatened by a virulent outbreak of spinach blight
(Cucumber Mosaic Virus or CMV; Kaplan 1998). Smith (1920) found that spinach accessions from Manchuria in China, collected during an expedition of the United States Department of Agriculture (USDA) 20 years earlier, were distasteful to the aphids that transmitted the virus. Smith was able to transfer this advantageous trait to American cultivars and selected 'Virginia Savoy' in 1921 when he crossed CMVresistant plants with 'Bloomsdale' (Fig. 9). This was the first documented case of resistance breeding in spinach. Cook et al. (1947) reported the development of a wilt resistant line by positive selection of 'Virginia 


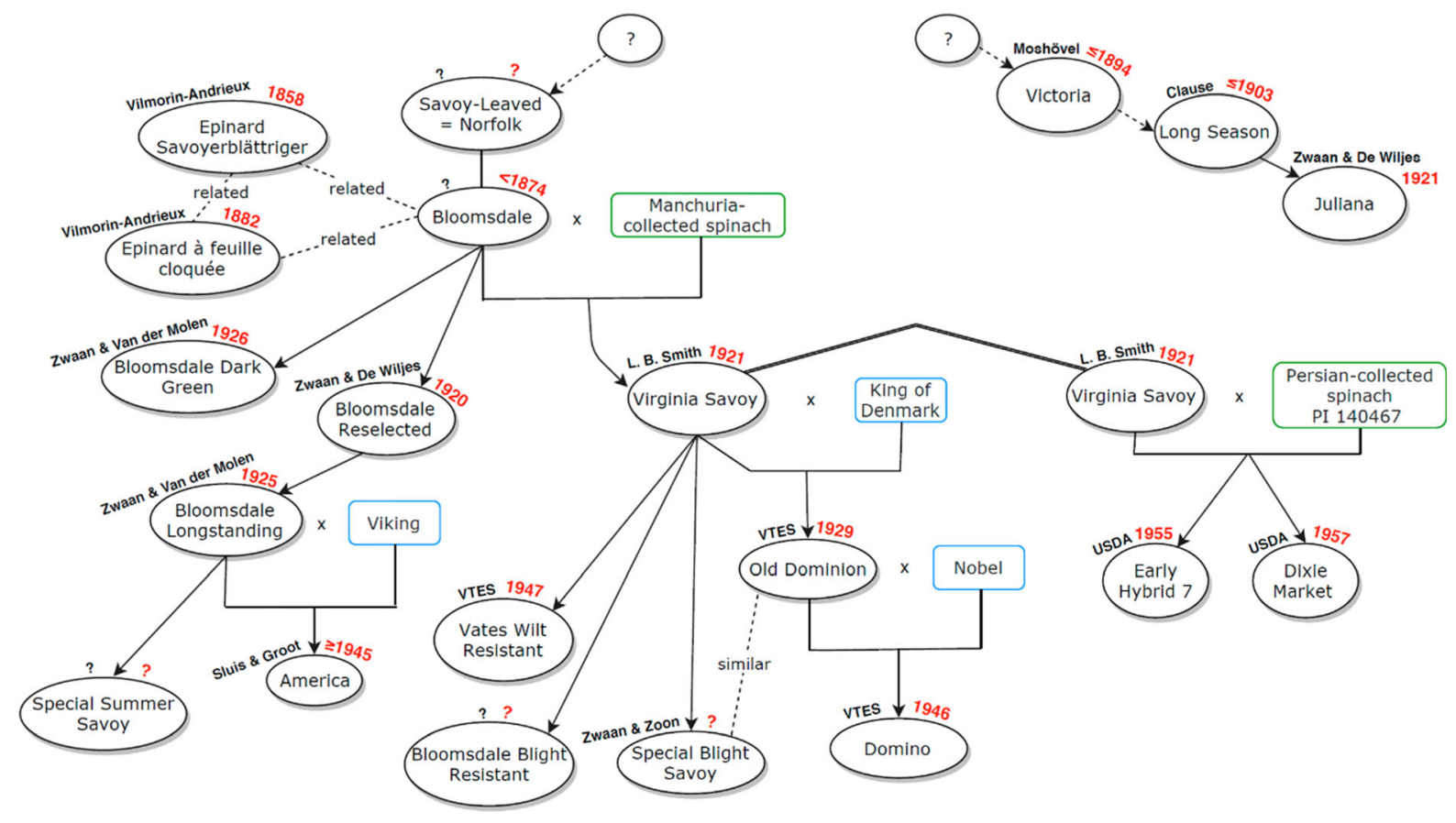

Fig. 9 Breeding history and ancestry of savoy-leaved, smooth-seeded spinach. See the box in Fig. 7 for explanation

Savoy' plants, which was commercialized in 1947 under the name 'Vates Wilt Resistant' (Fig. 9; Sherbakoff 1949).

\section{Downy mildew}

In addition to spinach blight, the spinach industry in the USA also faced problems with downy mildew (Kandel et al. 2019). The pathogen had already been identified as early as 1824 (Greville 1824) but it was not until 1946 that the USDA started to screen germplasm for resistance. One year later, resistance was identified in two wild accessions from Persia, namely PI 140464 and PI 140467 (Fig. 8; Smith 1950; Smith and Zahara 1956). This finding led to the first use of wild germplasm in spinach breeding as these two accessions were used by the USDA as source material to develop and release resistant $F_{1}$ hybrid cultivars such as the savoy-leaved 'Early Hybrid \#7' in 1955 and 'Dixie Market' in 1957 (Jones and Dainello 1982). These two cultivars were the first major commercial hybrids that were published, although Sneep (1983) stated that $F_{1}$ hybrids had been discussed in the literature since the 1930s. Smooth-leaved resistant cultivars were developed as well, and the first cultivar was commercialized in 1957 under the name 'Califlay', which resulted from a cross between PI 140467 and 'Viroflay' and the subsequent fourtimes-backcrossing to 'Viroflay' (Fig. 8; Smith and Zahara 1956).

After the arrival of the USDA hybrids, $F_{1}$ hybrid spinach became the standard in the spinach seed industry. In the beginning, hybrid production was laborious due to the need to rogue male plants from the normally dioecious female seed-producing plants. Nowadays, the process requires less input since the industry uses gynomonoecious and andromonoecious plants in order to enable development and maintenance of the parental lines used for hybrid production (Janick 1998; Morelock and Correll 2008).

In 1958, some 'Califlay' plants were infected by downy mildew in the USA and Europe because of the appearance of a new race of the pathogen, denominated as Pfs2 (Zink and Smith 1958; Smith et al. 1961). Interestingly, 'Early Hybrid \#7' and 'Dixie Market' were resistant to Pfs2 even though both hybrids and 'Califlay' had been developed using the same initial resistant accession PI 140467 (Jones et al. 1956; Smith et al. 1961). Later it was found that the source of resistance to Pfs2 was PI 140462, a Persian accession that had also been used to develop the parental lines for the hybrids. It was hypothesized that 
at least two genes were involved in the resistance, namely $M 1$, present in 'Califlay' and the hybrids, and $M 2$, only present in the hybrids (Smith et al. 1962). Later, Eenink (1976) found that $M 1$ and $M 2$ were closely linked genes involved in downy mildew resistance and were weakly linked with the gene involved in spinach blight resistance.

After the start of downy mildew resistance breeding in the late 1950s, the entire spinach breeding industry focused on introgressing both resistance genes into existing cultivars. 'Resistoflay', a new 'Viroflay'derived cultivar with both downy mildew resistances was developed (Koopmans 1965). In the Netherlands, the spinach industry boomed during the 1960s and many new and resistant cultivars derived from 'Resistoflay' or USDA resistant accessions were introduced to the market (Banga 1960; Banga and Koopmans 1962).

The downy mildew resistance lasted until 1976 when Pfs3 appeared in the Netherlands. However, 'Califlay' and its derived cultivars appeared resistant to this new race (Eenink 1976). This suggested the presence of a third resistance gene (M3) in 'Califlay' (Jones and Dainello 1982) and breeding efforts were directed to the development of cultivars with all three resistance genes. In 1978, new spinach cultivars resistant to all three races of downy mildew were introduced to the market (Morelock 1999).

It was not until 1990 that Pfs4, which was able to infect commercially available cultivars, appeared in California (Correll et al. 1990). Resistant cultivars entered the market as early as in 1991 (Morelock 1999). Brandenberger et al. (1991) stated that regarding the spinach breeding program in Arkansas the perspective had shifted from single-gene qualitative resistance to polygenic quantitative resistance against downy mildew. By 1994, horizontal resistance was reported for several cultivars released by the University of Arkansas during the 1980s, which had been selected from lines that displayed horizontal resistance to white rust (Brandenberger 1994; Morelock 1999). Parallel to the efforts on horizontal resistance breeding, screening of spinach germplasm was continued to identify resistance genes against Pfs4 (Brandenberger et al. 1992). Two accessions with high resistance against Pfs4 were found, namely $S$. oleracea SPI 82/87 originating from Iraq, and S. turkestanica CGN09546 from Uzbekistan (Morelock and Correll 2008).
Breeding for new downy mildew resistant cultivars is a continuous concern as new races of the pathogen keep appearing. In fact, downy mildew is still the main and one of the most destructive diseases of spinach at the global scale (Correll et al. 1994, 2011). To be able to respond to the rapid evolution of the pathogen, wild germplasm was increasingly being explored by breeders to find new resistance genes, which formed the basis of CGN's expeditions to collect $S$. turkestanica in 2008 and S. tetrandra in 2011 (Van Treuren et al. 2019).

The International Working Group on Peronospora (IWGP), supported by the University of Arkansas and the University of California, is a consortium of seed companies and the Netherlands Inspection Service for Horticulture (Naktuinbouw). The IWGP monitors the emergence and development of new spinach downy mildew races and decides on their official denomination (Plantum 2009). To date 17 races have been denominated by the IWGP, the most recent one in 2018 (Naktuinbouw 2018).

The introgression of qualitative resistance genes (R-genes) from germplasm is common procedure in breeding for downy mildew resistance in spinach (Correll et al. 2011). These R-genes, predominantly 'nucleotide binding site leucine-rich repeats' (NBSLRR) genes (Marone et al. 2013), confer pathogen resistance by encoding proteins specialized in recognizing pathogen-related molecules, which can trigger R-mediated defence (Gururani et al. 2012). Xu et al. (2017) identified 139 different NBS-LRR genes in the spinach genome, while Correll et al. (2011) hypothesized that 6 loci are controlling known downy mildew resistances. These loci are referred to as $R P F$ loci, but to date none have been identified nor cloned (She et al. 2018). Currently, up to 13 different $R P F$ loci have been described (Dijkstra 2015a, b, 2016). The IWGP members use a common differential set of cultivars that have different $R P F$ loci (Table 3) to characterize and identify new downy mildew isolates (International Seed Federation 2018; Feng et al. 2018). Some of these differentials are near-isogenic lines (NILs) that each contain a single $R P F$ locus (RPF1-6). Recently, comparative genomics research resulted in the identification of the RPF1 region and the inference of three potential candidate genes (Xu et al. 2017). Further experiments using similar approaches may help to identify the genomic location and DNA sequence of other RPF genes. Moreover, more detailed insight in 
Table 3 Differential set of spinach lines used for Pfs isolate identification a . Susceptible reactions are denoted by ' + ', resistant reactions by ' - ', intermediate resistant reactions by ' $(-)$ ' and variable reactions by ' \pm '

\begin{tabular}{|c|c|c|c|c|c|c|c|c|c|c|c|c|c|c|c|c|c|c|c|}
\hline \multirow[t]{2}{*}{ Differential cultivar $^{\mathrm{b}}$} & \multicolumn{2}{|c|}{ Parental resistance } & \multicolumn{17}{|c|}{ Downy mildew race (Pfs) } \\
\hline & Male & Female & 1 & 2 & 3 & 4 & 5 & 6 & 7 & 8 & 9 & 10 & 11 & 12 & 13 & 14 & 15 & 16 & 17 \\
\hline Viroflay & - & - & + & + & + & + & + & + & + & + & + & + & + & + & + & + & + & + & + \\
\hline Resistoflay & RPF5 & - & - & - & + & + & + & + & + & + & + & + & + & + & + & + & + & + & + \\
\hline Califlay & - & RPF3 & - & + & - & + & - & + & + & - & - & + & - & - & + & - & + & - & + \\
\hline Clermont & RPF4 & RPF5 & - & - & - & - & + & + & + & + & + & + & + & + & + & + & - & + & + \\
\hline Campania & RPF6 & RPF4 & - & - & - & - & - & + & - & + & + & + & - & + & \pm & + & - & - & + \\
\hline Boeing & RPF1 & RPF5 & - & - & - & - & - & - & - & + & - & + & - & + & - & + & - & + & + \\
\hline Lion & RPF1 & RPF3 & - & - & - & - & - & - & - & - & - & + & - & - & - & - & - & - & + \\
\hline Lazio & RPF2 & RPF4 & - & - & - & - & - & - & - & - & - & - & + & + & + & + & - & + & + \\
\hline Whale & - & RPF3 & - & - & - & $(-)$ & - & $(-)$ & $(-)$ & - & - & + & - & + & + & - & + & - & + \\
\hline Pigeon & RPF2 & RPF9 & - & - & - & - & - & - & - & - & - & - & - & - & - & + & - & + & + \\
\hline Caladonia & RPF3 & RPF9 & - & - & - & - & - & - & - & - & - & - & - & - & - & - & + & - & + \\
\hline Meerkat & RPF2 & RPF10 & - & - & - & - & - & - & - & - & - & - & - & - & - & - & - & + & $(-)$ \\
\hline Hydrus & $\mathrm{RPF} 11^{\mathrm{c}}$ & $\mathrm{RPF} 11^{\mathrm{c}}$ & - & - & - & - & - & - & - & - & - & - & - & - & - & - & - & - & - \\
\hline NIL1 & \multicolumn{2}{|c|}{ RPF1 } & - & - & - & - & - & - & - & + & - & + & - & + & - & + & - & - & + \\
\hline NIL2 & \multicolumn{2}{|c|}{ RPF2 } & - & - & - & - & - & - & - & - & - & - & + & + & + & + & - & + & + \\
\hline NIL3 & \multicolumn{2}{|c|}{ RPF3 } & - & + & - & + & - & + & + & - & - & + & - & - & + & - & + & - & + \\
\hline NIL4 & \multicolumn{2}{|c|}{ RPF4 } & - & - & - & - & + & + & + & + & + & + & + & + & + & + & - & + & + \\
\hline NIL5 & \multicolumn{2}{|c|}{ RPF5 } & - & - & + & + & + & + & + & + & + & + & + & + & + & + & + & + & + \\
\hline NIL6 & \multicolumn{2}{|c|}{ RPF6 } & - & + & - & - & - & + & - & + & + & + & - & + & $(-)$ & + & - & - & + \\
\hline
\end{tabular}

${ }^{\mathrm{a}}$ Data from International Seed Federation (2018)

${ }^{b}$ The cultivars Resistoflay to Lazio can be replaced by the near-isogenic lines (NILs)

${ }^{\mathrm{c}}$ Which parental line is responsible for the RPF locus is not specified (Dijkstra 2015a)

the structure of $\mathrm{R}$ proteins would contribute to a better understanding of the mechanisms underlying the interaction with their ligands.

R-gene resistance follows a gene-for-gene interaction. Consequently, their effectiveness is rapidly lost when a new virulent race appears, as the pathogen has a large selective advantage and will spread quickly among genetically similar plants (Brown 2015). Although methods exist that can slow down the breakdown of R-genes, such as gene stacking and cultivating mixtures of cultivars with different resistance genes (Brown 2015), the emergence of hypervirulent races or races without a matching resistance locus can be disastrous for spinach cultivation (Kapos et al. 2019). As currently the major approach to obtain downy-mildew resistance relies on temporary solutions, there is an urgent need to find durable resistance.
A compatible host-pathogen interaction requires the expression of specific host genes, the so-called susceptibility genes (S-genes; Pavan et al. 2010; Van Schie and Takken 2014). Mutation or loss of an S-gene can lead to recessive durable resistance (Brown 2015). S-genes associated with downy mildew susceptibility, denoted as Downy Mildew Resistance $(D M R)$ genes, have been found in A. thaliana (DMR1-6; Van Damme et al. 2005, 2008). These genes probably have a conserved function across plant species. Schouten et al. (2014) and Porterfield and Meru (2017) used $D M R 1$ and DMR6 to search for novel DMR candidate genes in the Cucurbitaceae family. Huibers et al. (2013) studied the DMRI orthologue in S. lycopersicum (SIDMRI) and found that gene silencing was associated with resistance against late blight caused by the oomycete Phytophthora infestans, although it also caused detrimental effects on plant growth. Sun et al. 
(2016) reported six susceptibility genes for late blight in potato. Although no records of S-genes in Spinacia species have been found in the literature, breeding for mutant S-genes could be a promising approach to develop spinach cultivars that are resistant to rapidly evolving pathogens such as downy mildew.

\section{White rust}

White rust, caused by the oomycete Albugo occidentalis, is another disease affecting spinach cultivation. White rust is mainly present in the spinach producing areas east of the Rocky Mountains in the United States (Correll et al. 1994; Koike et al. 2006), although outbreaks have occurred also in Iran (Ebrahimi and Afzali 2000), Greece (Vakalounakis and Doulis 2013), Mexico (Correll et al. 2017) and Turkey (Soylu et al. 2018). Geographical expansion of white rust may form a potential threat to spinach cultivation.

White rust was recognized as a serious disease during the 1930s and 1940s in the USA (Brandenberger et al. 1992). However, the first cultivars with partial resistance to white rust were not released until 1975 by the USDA (Brandenberger 1994). In contrast to downy mildew, no qualitative resistance against white rust has been reported (Correll et al. 2017) and quantitative approaches have been used to mitigate the effects of the disease. According to Bowers (1972), the commercial 'Hybrid 178' and the USDA breeding line 'WRG 70-5' formed the basis to develop resistant cultivars. In 1987, the improved open-pollinated cultivar 'Fallgreen' with a high resistance level was released by the University of Arkansas (Morelock 1999). Although new open-pollinated resistant cultivars were developed, the former materials were used by the spinach breeding industry to create white rust resistant hybrids (Morelock and Correll 2008).

\section{Leaf spot diseases}

Ascomycete fungi are the main causal agents for the emergence of leaf spot diseases (Koike et al. 2006). The main ascomycetes responsible for leaf spots in spinach are Colletotrichum dematium, causing anthracnose, Stemphylium botryosum and Cladosporium variabile (De Visser 2015; Liu et al. 2018). In addition, Cercospora beticola, Colletotrichum coccodes, $C$. truncatum and Myrothecium verrucaria are minor agents causing leaf spot diseases in spinach (Liu et al. 2018).

Although literature on breeding for resistance against leaf spot pathogens is scarce, variation in tolerance to $C$. dematium isolates among different spinach cultivars has been reported (Correll et al. 1993). Also partial resistances to $S$. botryosum and $C$. variabile have been observed in spinach germplasm (Mou et al. 2008). Furthermore, molecular markers associated with resistance against $S$. botryosum have been identified (Shi et al. 2016a).

\section{Soilborne diseases}

Soilborne diseases are commonly expressed as root rot and damping off at very early plant stages. The major causal agents of soilborne diseases are fungi, such as Fusarium oxysporum, other Fusarium species and Rizoctonia solani and oomycetes, such as Aphanomyces cochlioides and several Pythium species (Correll et al. 1994; Koike et al. 2006; De Visser 2015). As Pythium spp. are the main agents for damping off in spinach, available germplasm is being investigated for variation in resistance to these species (Magnée et al. 2017).

Wilt caused by Fusarium oxysporum and Verticillium spp. (e.g. V. dahliae) is also threatening spinach cultivation (Correll et al. 1994; Koike et al. 2006). Regarding $V$. dahliae, molecular markers associated with resistance to the fungus have been identified (Shi et al. 2016b).

\section{Insects}

Damage to spinach cultivation by insects has been reported for green peach aphids, garden webworms, Hawaiian beet webworms, southern beet webworm, seed-corn maggots, cabbage loopers, cucumber beetles, grasshoppers and leafhoppers (Morelock and Correll 2008). However, our literature survey did not reveal any genetic studies or breeding programs regarding resistance against these pests.

The leafminer Liriomyza langei is considered a serious threat to spinach production in the United States. Adult flies of this species feed on the plant sap after puncturing of the leaves, while feeding by larvae causes the typical winding mines in leaves. The resulting reduction in photosynthetic capacity negatively affects the marketability of spinach. As the use 
of insecticides is still common practice, host genetic resistance would offer an efficient strategy to control the disease. Screening of 345 accessions of the US spinach collection has shown genetic variability for leafminer resistance (Mou 2008b), and a subsequent genetic study revealed five SNPs associated with this trait (Shi and Mou 2016). It was concluded from these studies that leafminer resistance can be improved and combined with yield traits in cultivars and that the identified SNP markers may be useful for markerassisted selection in spinach breeding programs. To date, highly resistant commercial cultivars have not yet been developed.

\section{Breeding for abiotic stress tolerance}

Spinach has been investigated for its tolerance to abiotic factors such as water stress (Zuccarini and Savé 2016; Ors and Suarez 2017), salinity and osmotic stress (Bagheri et al. 2015; Ors and Suarez 2016, 2017; Ferreira et al. 2018), heavy metal stress (Fagioni et al. 2009; Bagheri et al. 2015) and temperature stress (Mogren et al. 2015; Chitwood et al. 2016; Ors and Suarez 2016). Two genes involved in tolerance to osmotic stress have been identified (Weretilnyk and Hanson 1988; Burnet et al. 1995; Hibino et al. 2002), but in general the genetics of tolerance against abiotic stresses is rather understudied in spinach.

Adaptation to low nitrogen availability is an important aspect in the development of sustainable and more efficient agriculture (Witcombe et al. 2008). In this context, the two QTL regions related to growth in nitrogen-poor conditions identified by Chan-Navarrete et al. (2016) will contribute to the improvement of nitrogen use efficiency in spinach.

To date, abiotic stress improvement is largely unexplored in spinach as the available literature on this topic is rather scarce. As climate change is expected to pose serious challenges to agriculture (Pereira 2016), research on abiotic stress tolerance will most likely gain considerable importance in spinach breeding in the near future.

\section{Breeding for quality}

The chemical composition of spinach has been shown to differ significantly between cultivars, including oxalic acid, nitrate, vitamin $\mathrm{C}$, lutein, carotenoid and phenolic content (Murphy and Morelock 2000;
Murphy 2001; Howard et al. 2002; Pandjaitan et al. 2005; Solberg et al. 2015; Wang et al. 2018b). Although nutritional composition is known to be influenced by factors such as cultivation method and storage procedures (Lester et al. 2010; Koh et al. 2012), the large variation observed among cultivars indicates a genetic basis, suggesting that nutritional quality can be improved by plant breeding (Howard et al. 2002); Morelock and Correll 2008; Wang et al. 2018b).

Maximizing health-related compounds and minimizing oxalic acid and nitrate content are important targets in improving the quality of spinach cultivars. Shi et al. (2016c) identified SNP markers associated with oxalate concentration in spinach, while Qin et al. (2017) identified SNP markers associated with 13 different mineral elements. In both studies, the identified materials with breeding potential were cultivated spinach accessions from diverse origins, including both landraces and modern cultivars. Additionally, the two QTLs related to nitrogen use efficiency (ChanNavarrete et al. 2016) could be helpful to reduce nitrate levels in spinach leaves by minimizing the amount of applied fertilizer.

Differences in the concentration of phenolics and flavonoids between modern cultivars differing in the level of resistance against downy mildew and white rust have been detected by Howard et al. (2002). In addition, Pandjaitan et al. (2005) reported that the level of phenolics and flavonoids in spinach leaves depended on the maturity stage, mid-mature leaves showing the highest levels in comparison with baby and adult leaves. Recently, a red spinach cultivar with an increased antioxidant content was released (Mou 2019). This cultivar is rich in betacyanin and has been selected from a red-veined spinach cultivar.

Morphological traits are highly important for a better appearance and easier processing of spinach plants. Recently, Cai et al. (2018) identified a major QTL and three candidate genes associated with leaf colour. Ma et al. (2016) identified SNP markers related to petiole colour, leaf texture and leaf margin shape, while Chitwood et al. (2016) reported SNP markers associated with leaf erectness, plant size and bolting. A better understanding of the mechanisms involved in bolting time is important in spinach breeding as it would enable the development of bolting-resistant cultivars with an extended period of leaf production. 
Cultivar development would highly benefit from an improved insight how monoecism and dioecism are controlled. Several markers associated with these reproductive characters have been found (Khattak et al. 2006; Onodera et al. 2011; Yamamoto et al. 2014), while Qian et al. (2017) identified two potential genomic regions harbouring the $\mathrm{X} / \mathrm{Y}$ sex-determining gene. Nevertheless, as sex expression in spinach is still not well understood, further research is needed before this character can be exploited in spinach breeding.

\section{Future perspectives}

\section{Genetic resources}

Current data suggest that Spinacia tetrandra belongs to the secondary rather than to the primary gene pool of spinach. To substantiate this finding crossing experiments with cultivated spinach are needed along with more detailed molecular analyses to reveal species relationships.

The underrepresentation of crop wild relatives in genetic resources collections is limiting future spinach research and breeding. As many wild species are under pressure in their natural habitat, for instance due to climatic changes, valuable genetic resources for crop breeding may go extinct. The stricter requirements regarding access and benefit sharing are hampering new collecting expeditions to enrich genetic resources collections. It is therefore imperative that access and benefit issues are soon adequately arranged by the international political community in order to open up countries for the collecting of valuable genetic resources that can be exploited in crop breeding.

\section{Domestication}

Although spinach is considered to have spread from its presumed domestication area in Iran to China and Europe, the exact migration routes are not completely clear. For example, spinach cultivation may have been introduced in Europe via North Africa but also via the Balkan. Data on the genetic structure of landraces originating from alternative routes are needed to reveal the most probable migration routes of spinach after domestication.
Crop breeding

In 2017, an assembly of the spinach genome was published (Xu et al. 2017), which is available from SpinachBase (http://www.spinachbase.org). The spinach genome has an estimated size of $\sim 1000 \mathrm{Mb}$, containing $74.4 \%$ of repetitive sequences and an approximate number of 25,500 protein-coding genes. Previous research revealed a total of 93 genomic regions associated with wild species introgressions that are potentially related with spinach domestication and breeding (Xu et al. 2017). Comparative genomics approaches between cultivated spinach and its main wild relatives are currently hampered by the fact that genome assemblies of $S$. turkestanica and $S$. tetrandra are lacking. In cooperation with several breeding companies, we have initiated research to develop reference genomes for these two species. In addition, this study will include the resequencing of available genetic resources of the species. It is anticipated that the results of this study will greatly facilitate the exploitation of the genetic diversity of the wild species in spinach breeding for new robust cultivars that are more resilient to biotic and abiotic stresses.

Breeding for downy mildew resistance using NBSLRR genes has been shown to provide only short-term solutions as these genes are usually broken down by new races of the disease. Therefore, more durable strategies for downy mildew resistance are clearly needed. An interesting new approach is the inactivation of S-genes as this strategy has been reported to be effective against downy mildew infection, such as in case of the DMR genes in Arabidopsis.

Climate change is expected to have a large negative impact on global crop cultivation. The increase in global temperatures poses major challenges to spinach cultivation because of unpredictable heat and drought periods. In addition to heat and drought stress, also salt stress is expected to become a problem due to increases in soil water evaporation resulting in the increase of mineral salts in topsoil layers. As severe declines in crop yield can be expected, the breeding of new spinach cultivars that are more resilient to these abiotic stresses is clearly needed.

Acknowledgements The contribution of RvT and CK was carried out in the framework of the Programme Genetic Resources (WOT-03) funded by the Dutch Ministry of Agriculture, Nature and Food Quality. 
Author contributions This study was initiated by CK. All authors contributed to the study conception and design. Data collection and analysis were performed by AR, who also prepared the first draft of the manuscript. All authors commented on previous versions of the manuscript. All authors read and approved the final manuscript.

\section{Compliance with ethical standards}

Conflict of interest The authors declare that no financial benefits will result from publication of the research. Furthermore, the authors are unaware of any actual or potential conflict of interest that could inappropriately influence, or be perceived to influence, our work. To the best of our knowledge, the research was carried out according to appropriate ethical principles.

Open Access This article is licensed under a Creative Commons Attribution 4.0 International License, which permits use, sharing, adaptation, distribution and reproduction in any medium or format, as long as you give appropriate credit to the original author(s) and the source, provide a link to the Creative Commons licence, and indicate if changes were made. The images or other third party material in this article are included in the article's Creative Commons licence, unless indicated otherwise in a credit line to the material. If material is not included in the article's Creative Commons licence and your intended use is not permitted by statutory regulation or exceeds the permitted use, you will need to obtain permission directly from the copyright holder. To view a copy of this licence, visit http://creativecommons.org/licenses/by/4.0/.

\section{References}

Astley D, Ford-Lloyd BV (1981) The evolutionary significance of multigermicity in the genus Spinacia (Chenopodiaceae). Plant Syst Evol 137:57-61

Bagheri R, Bashir H, Ahmad J, Iqbal M, Qureshi MI (2015) Spinach (Spinacia oleracea L.) modulates its proteome differentially in response to salinity, cadmium and their combination stress. Plant Physiol Biochem 97:235-245

Banga O (1960) 12e Beschrijvende Rassenlijst voor Groentegewassen. Wageningen, IVT, pp 112-117

Banga O, Koopmans W (1962) 14e Beschrijvende Rassenlijst voor Groentegewassen. Wageningen, IVT, pp 124-132

Bentsink L, Koornneef M (2008) Seed dormancy and germination. Arabidopsis Book 6:e0119

Bock H (1539) Kreüter Buch. Wendel Rihel, Strassburg, np. https://reader.digitale-sammlungen.de/de/fs1/object/ display/bsb11069345_00001.html. Accessed 5 Feb 2019

Bock H (1546) Kreüter Buch. Wendel Rihel, Strassburg, pp 276278. https://archive.org/details/mobot31753000815859/ page/n3. Accessed 5 Feb 2019

Bohn T, Davidsson L, Walczyk T, Hurrell RF (2004) Fractional magnesium absorption is significantly lower in human subjects from a meal served with an oxalate-rich vegetable, spinach, as compared with a meal served with kale, a vegetable with a low oxalate content. Br J Nutr 91:601-606
Boswell VR (1949) Garden peas and spinach from the Middle East. Reprint of 'Our Vegetable Travelers'. Natl Geogr 96:2

Bowers JL (1972) Spinach breeding program for disease resistance in Arkansas. Proc Ark State Hort Soc 93:53-54

Brandenberger LP (1994) Characterization of resistance of spinach to white rust (Albugo occidentalis) and downy mildew (Peronospora farinosa f. sp. spinaciae). Phytopathology 84:431-437

Brandenberger LP, Correll JC, Morelock TE (1991) Identification of and cultivar reactions to a new race (race 4) of Peronospora farinosa f. sp. spinaciae on spinach in the United States. Plant Dis 75:630-634

Brandenberger LP, Morelock TE, Correll JC (1992) Evaluation of spinach germplasm for resistance to a new race (race 4) of Peronospora farinosa f. sp. spinaciae. HortScience 27(20):1118-1119

Brown JKM (2015) Durable resistance of crops to disease: a Darwinian perspective. Ann Rev Phytopathol 53:513-539

Bunea A, Andjelkovic M, Socaciu C, Bobis O, Neacsu M, Verhé R, Van Camp J (2008) Total and individual carotenoids and phenolic acids content in fresh, refrigerated and processed spinach (Spinacia oleracea L.). Food Chem 108:649-656

Burnet M, Lafontaine PJ, Hanson AD (1995) Assay, purification, and partial characterization of choline monooxygenase from spinach. Plant Physiol 108(2):581-588

Cai X, Xu C, Wang X, Wang S, Zhang Z, Fei Z, Wang Q (2018) Construction of genetic linkage map using genotyping-bysequencing and identification of QTLs associated with leaf color in spinach. Euphytica 214:229

Chan-Navarrete R, Dolstra O, van Kaauwen M, van Bueren ET, van der Linden CG (2016) Genetic map construction and QTL analysis of nitrogen use efficiency in spinach (Spinacia oleracea L.). Euphytica 208:621-636

Chitwood J, Shi A, Mou B, Evans M, Clark J, Motes D, Chen P, Hensley D (2016) Population structure and association analysis of bolting, plant height, and leaf erectness in spinach. HortScience 51:481-486

Chun OK, Kim D-O, Smith N, Schroeder D, Han JT, Lee CY (2005) Daily consumption of phenolics and total antioxidant capacity from fruit and vegetables in the American diet. J Sci Food Agric 85:1715-1724

Cook HT, Nugent TJ, Parris GK, Porter RF (1947) Fusarium wilt of spinach and the development of a wilt resistant variety. Va Truck Exp Sta Bull 110:1810-1820

Correll JC, Koike ST, Brandenberger LP, Black M, Morelock TE (1990) A new race of downy mildew threatens spinach. Calif Agric 44:14-15

Correll JC, Morelock TE, Guerber JC (1993) Vegetative compatibility and virulence of the spinach anthracnose pathogen, Colletotrichum dematium. Plant Dis 77:688-691

Correll JC, Morelock TE, Black MC, Koike ST, Brandenberger LP, Dainello FJ (1994) Economically important diseases of spinach. Plant Dis 78:653-660

Correll JC, Bluhm BH, Feng C, Lamour K, du Toit L, Koike ST (2011) Spinach: better management of downy mildew and white rust through genomics. Eur J Plant Pathol 129:193-205

Correll JC, Feng CD, Liu B (2017) First report of white rust (Albugo occidentalis) of spinach in Mexico. Plant Dis 101:511 
De Visser J (2015) The challenges of spinach breeding. International Spinach Conference, Yuma, 24-25 February 2015. https://cpb-us-e1.wpmucdn.com/wordpressua.uark.edu/ dist/0/310/files/2017/06/The-challenges-of-spinachbreeding-Jan-de-Visser.pdf. Accessed 5 May 2019

Decoteau DR (2000) Vegetable Crops. Prentice-Hall, Upper Saddle River

Deleuran LC (2010) Innovation in vegetable seed production and the role of consumers in the organic and conventional babyleaf chains: the case of Denmark. Renew Agric Food Syst 26:149-160

Dijkstra JA (2015a) Spinach plants that are resistant to downy mildew. European patent EP 2848114

Dijkstra JA (2015b) Spinach plants that are resistant to downy mildew. International patent WO 2015/036378

Dijkstra JA (2016) Spinach plants that are resistant to downy mildew. United States patent US 2016/0177330

Ebrahimi AG, Afzali H (2000) Albugo occidentalis, a new fungus to Iran. Rostaniha 1:73

Eenink AH (1976) Linkage in Spinacia oleracea L. of two racespecific genes for resistance to downy mildew Peronospora farinosa f. sp. spinaciae Byford. Euphytica 25:713-715

El Faïz M (1995) L'agronomie de la Mésopotamie Antique. Analyse du Livre de l'Agriculture Nabatéenne de Qûtâma. Brill, Leiden

El Faïz M (2000) Ibn al- 'Awwâm, Kitâb al-Filâha (Le livre de l'agriculture 12th c. A.D.). Clément-Mullet, translator. Actes Sud, Arles

Ermer T, Eckardt K-U, Aronson PS, Knauf F (2016) Oxalate, inflammasome, and progression of kidney disease. Curr Opin Nephrol Hypertens 25(4):363-371

Fagioni M, D'Amici GM, Timperio AM, Zolla L (2009) Proteomic analysis of multiprotein complexes in the thylakoid membrane upon cadmium treatment. J Proteome Res 8:310-326

FAOSTAT (2018) Statistics division of the Food and Agriculture Organization (FAO) of the United Nations. Rome. https://www.fao.org/faostat. Accessed 16 May 2019

Feng C, Saito K, Liu B, Manley A, Kammeijer K, Mauzey SJ, Koike S, Correll JC (2018) New races and novel strains of the spinach downy mildew pathogen Peronospora effusa. Plant Dis 102:613-618

Ferreira JFS, Sandhu D, Liu X, Halvorson JJ (2018) Spinach (Spinacea oleracea L.) response to salinity: nutritional value, physiological parameters, antioxidant capacity, and gene expression. Agriculture 8:163

Finch-Savage WE, Bassel GW (2016) Seed vigour and crop establishment: extending performance beyond adaptation. J Exp Bot 67:567-591

Fuchs L (1543) New Kreüterbuch. Michael Isingrin, Basell, pp 667-669. https://publikationen.uni-tuebingen.de/xmlui/ bitstream/handle/10900/43794/html/lo-res/index. html? sequence=2\&isAllowed=y. Accessed 5 Feb 2019

Fujito S, Takahata S, Suzuki R, Hoshino Y, Ohmido N, Onodera Y (2015) Evidence for a common origin of homomorphic and heteromorphic sex chromosomes in distinct Spinacia species. Genes Genom Genet 5:1663-1673

Gibault G (1912) Histoire des légumes. Paris: Libraire Horticole. pp 81-88. https://gallica.bnf.fr/ark:/12148/ bpt6k6422705t/f5.item. Accessed 11 Mar 2019
Greville RK (1824) Flora Edinensis. William Blackwood, Edinburgh, pp 468. https://www.biodiversitylibrary.org/ item/123499\#page/562/mode/1up. Accessed 15 Mar 2019

Gururani MA, Venkatesh J, Upadhyaya CP, Nookaraju A, Pandey SK, Park SW (2012) Plant disease resistance genes: current status and future directions. Physiol Mol Plant Pathlol 78:51-65

Hallavant C, Ruas M-P (2014) The first archaeobotanical evidence of Spinacia oleracea L. (spinach) in late 12th-mid 13th century a.d., France. Veget Hist Archaeobot 23:153-165

Hassler M (2018) World Plants: Synonymic Checklists of the Vascular Plants of the World (version April 2018). In: Roskov Y, Abucay L, Orrell T, Nicolson D, Flann C, Bailly N, Kirk P, Bourgoin T, DeWalt RE, Decock W, De Wever A (eds) Species 2000 \& ITIS Catalogue of Life, 2018 Annual Checklist. Species 2000, Naturalis, Leiden. www. catalogueoflife.org/annual-checklist/2018. Accessed 2 May 2019

Heaney RP, Weaver CM, Recker RR (1988) Calcium absorbability from spinach. Am J Clin Nutr 47:707-709

Heine P (2018) The culinary crescent: a history of Middle Eastern Cuisine. Lewis P, translator. Gingko Library, London

Hibino T, Waditee R, Araki E, Ishikawa H, Aoki K, Tanaka Y, Takabe T (2002) Functional characterization of choline monooxygenase, an enzyme for betaine synthesis in plants. J Biol Chem 277:41352-41360

Howard LR, Pandjaitan N, Morelock T, Gil MI (2002) Antioxidant capacity and phenolic content of spinach as affected by genetics and growing Season. J Agric Food Chem 50:5891-5896

Huibers RP, Loonen AEHM, Gao D, Van den Ackerveken G, Visser RGF, Bai Y (2013) Powdery Mildew resistance in tomato by impairment of SIPMR4 and SIDMR1. PLoS ONE 8(6):e67467

International Seed Federation (2018) Differential Sets. Peronospora farinosa f. sp. spinaciae ( $P$. effusa). ISF, Nyon. https://www.worldseed.org/wp-content/uploads/2018/04/ Spinach-downy-mildew_April2018.pdf. Accessed 2 May 2019

Janick J (1998) Hybrids in horticultural crops. In: Lamkey KR, Staub JE (eds) Concepts and breeding of heterosis in crop plants. Crop Science Society of America, Madison, pp 45-56 (CSSA Special Publication N. 25)

Jones RK, Dainello FJ (1982) Occurrence of race 3 of Peronospora effusa on spinach in Texas and identification of sources of resistance. Plant Dis 66:1078-1079

Jones HA, McClean DM, Perry BA (1956) Breeding hybrid spinach resistant to mosaic and downy mildew. Proc Am Soc Hortic Sci 68:304-308

Kandel SL, Mou B, Shishkoff N, Shi A, Subbarao KV, Klosterman SJ (2019) Spinach downy mildew: advances in our understanding of the disease cycle and prospects for disease management. Plant Dis 103:791-803

Kaplan JK (1998) Conserving the world's plants. Agric Res 46:4-9

Kapos P, Devendrakumar KT, Li X (2019) Plant NLRs: from discovery to application. Plant Sci 279:3-18 
Kelsay JL, Prather ES (1983) Mineral balances of human subjects consuming spinach in a low-fiber diet and in a diet containing fruits and vegetables. Am J Clin Nutr 38:12-19

Khattak JZK, Torp AM, Andersen SB (2006) A genetic linkage map of Spinacia oleracea and localization of a sex determination locus. Euphytica 148:311-318

Kik C (2008) Report of a Spinacia collecting expedition to Uzbekistan and Tajikistan. Wageningen: Centre for Genetic Resources, the Netherlands (CGN). CGN Report 2008/12. https://missions.cgn.wur.nl/NUT/docs/ rapportNUT.pdf. Accessed 24 Jan 2019

Kinney LF (1896) Spinach. Bull Agr Exp Sta Rhode Island Coll Agr and Mech Arts 41:32

Koh E, Charoenprasert S, Mitchell AE (2012) Effect of organic and conventional cropping systems on ascorbic acid, vitamin $\mathrm{C}$, flavonoids, nitrate, and oxalate in 27 varieties of spinach (Spinacia oleracea L.). J Agric Food Chem 60:3144-3150

Koike ST, Gladders P, Paulus AO (2006) Vegetable Diseases. A Colour Handbook. Manson Publishing, London, pp 368-372

Komai F, Masuda K (2004) Plasticity in sex expression of spinach (Spinacia oleracea) regenerated from root tissues. Plant Cell, Tissue Organ Cult 78:285-287

Koopmans W (1965) 17e Beschrijvende Rassenlijst voor Groentegewassen. Wageningen, IVT, pp 129-139

Krarup C, Moreira I (1998) Hortalizas de estación fría. Biología y diversidad cultural. Santiago (CL): Universidad Católica de Chile. http://www7.uc.cl/sw_educ/hort0498/HTML/ p002.html. Accessed 12 Dec 2018

Laufer B (1919) Sino-Iranica; Chinese Contributions to the History of Civilization in Ancient Iran, with Special Reference to the History of Cultivated Plants and Products. Field Museum of Natural History, Chicago, pp 392-398. https://archive.org/stream/sinoiranicachine153lauf?ref= ol\#page/n7/mode/2up. Accessed 28 Mar 2019

Lester GE, Makus DJ, Hodges DM (2010) Relationship between fresh-packaged spinach leaves exposed to continuous light or dark and bioactive contents: effects of cultivar, leaf size, and storage duration. J Agric Food Chem 58:2980-2987

Liu B, Feng C, Correll J, Stein L, Cochran K, du Toit L (2018) Texas spinach leaf spots: pathogen diagnosis and disease management. International Spinach Conference, Murcia, Spain, 14-15 February 2018. https://cpb-us-e1.wpmucdn. com/wordpressua.uark.edu/dist/0/310/files/2018/03/3.1. Bo-urefdd.pdf. Accessed 16 May 2019

Ma J, Shi A, Mou B, Evans M, Clark JR, Motes D, Correll JC, Xiong H, Qin J, Chitwood J, Weng Y (2016) Association mapping of leaf traits in spinach (Spinacia oleracea L.). Plant Breed 135:399-404

Magnée K, Scholten OE, Lammerts van Bueren E, Groot SPC, Postma J (2017) Veredelingsonderzoek naar damping-off in spinazie: Groene Veredeling Spinazie. Wageningen University and Research, Wageningen. https://edepot.wur. nl/444226. Accessed 2 Apr 2019

Marone D, Russo AM, Laidò G, De Leonardis MA, Mastrangelo MA (2013) Plant nucleotide binding site-leucine-rich repeat (NBS-LRR) genes: active guardians in host defense responses. Int J Mol Sci 14:7302-7326

Miller P (1731) The Gardener's dictionary: containing the methods of cultivating and improving the kitchen, fruit and flower garden. C. Rivington, London, pp 411-415. https:// archive.org/details/gardenersdictio00millgoog/page/n8. Accessed 7 Feb 2019

Miller P (1768) The Gardener's dictionary: containing the methods of cultivating and improving the kitchen, fruit and flower garden. J\&F Rivington, London, pp 1107-1109. https://www.biodiversitylibrary.org/item/10276\#page/2/ mode/1up. Accessed 7 Feb 2019

Mogren L, Reade J, Monaghan J (2015) Potential for controlled abiotic stress as a quality enhancer of baby leaf spinach. Acta Hortic 1099:407-412

Mohebodini M, Sabaghnia N, Behtash F, Janmohammadi M (2017) Principal component analysis of some quantitative and qualitative traits in Iranian spinach landraces. Proc Latv Acad Sci 71:307-310

Morelock TE (1999) Spinach. In: Wehner TC (ed) Vegetable cultivar descriptions for North America List 25, vol 34. HortScience, Dordrecht, pp 987-988

Morelock TE, Correll JC (2008) Spinach. In: Prohens J, Nuez F (eds) Vegetables I: Asteraceae, Brassicaceae, Chenopodicaceae, and Cucurbitaceae. Springer, New York, pp 189-218

Mou B (2008a) Evaluation of oxalate concentration in the U.S. spinach germplasm collection. HortScience 43:1690-1693

Mou B (2008b) Leafminer resistance in spinach. HortScience 43:1716-1719

Mou B (2019) 'USDA Red' spinach. HortScience 54:2070-2072

Mou B, Koike ST, du Toit LJ (2008) Screening for resistance to leaf spot diseases of spinach. HortScience 43:1706-1710

Murphy JB (2001) Lutein content of spinach cultivars and breeding lines. National Spinach Conference, 14-15 November 2001, Fayetteville, pp 4

Murphy JB, Morelock TE (2000) Spinach breeding program yields lines containing high levels of carotenoid antioxidants. In: Richardson MD, Clark JR (eds) Horticultural studies, research series, vol 475. University of Arkansas, Fayetteville, pp 36-39

Naktuinbouw (2018) Press Release 2018 April 26, Denomination of Pfs: 17, a new race of downy mildew in spinach. Naktuinbouw, Roelofarendsveen. https://www. naktuinbouw.com/about-naktuinbouw/news/ denomination-pfs-17-new-race-downy-mildew-spinach. Accessed 18 Jan 2019

Noonan SC, Savage G (1999) Oxalate content of foods and its effect on humans. Asia Pac J Clin Nutr 8:64-74

Onodera Y, Yonaha I, Masumo H, Tanaka A, Niikura S, Yamazaki S, Mikami T (2011) Mapping of the genes for dioecism and monoecism in Spinacia oleracea L.: evidence that both genes are closely linked. Plant Cell Rep 30:965-971

Ors S, Suarez D (2016) Salt tolerance of spinach as related to seasonal climate. Hortic Sci 43:33-41

Ors S, Suarez DL (2017) Spinach biomass yield and physiological response to interactive salinity and water stress. Agric Water Manag 190:31-41

Pandey SC, Kalloo G (1993) Spinach Spinacia oleracea L. In: Kalloo G, Bergh BO (eds) Genetic improvement of vegetable crops. Pergamon Press, Oxford, pp 325-335

Pandjaitan N, Howard LR, Morelock T, Gil MI (2005) Antioxidant capacity and phenolic content of spinach as 
affected by genetics and maturation. J Agric Food Chem 53:8618-8623

Parkinson J (1904) Paradisi in Sole Paradisus Terrestris. Methuen \& Co, London, pp 496-497. (Reprinted from: Paradisi in Sole Paradisus Terrestris, 1629, by J. Parkinson, (np)). https://archive.org/details/paradisiinsolepa00parkrich/ page/n5. Accessed 8 Feb 2019

Pavan S, Jacobsen E, Visser RGF, Bai Y (2010) Loss of susceptibility as a novel breeding strategy for durable and broad-spectrum resistance. Mol Breed 25:1-12

Pereira A (2016) Plant abiotic stress challenges from the changing environment. Front Plant Sci 7:1123

Plantum (2009) Persbericht 30 January 2009. Wereldwijde opkomst van nieuw fysio valse meeldauw in spinazie. Plantum, Gouda. https://www.plantum.nl/document? documentregistrationid $=2316997144$. Accessed 18 Jan 2019

Porterfield R, Meru G (2017) Candidate susceptibility genes for powdery and downy mildew in watermelon and squash. J Phylogenetics Evol Biol 5:1-14

Qian W, Feng CD, Zhang HL, Liu W, Xu DH, Correll JC, Xu ZS (2016) First report of race diversity of the spinach downy mildew pathogen, Peronospora effusa, in China. Plant Dis 100: 1248

Qian W, Fan G, Liu D, Zhang H, Wang X, Wu J, Xu Z (2017) Construction of a high-density genetic map and the X/Y sex-determining gene mapping in spinach based on largescale markers developed by specific-locus amplified fragment sequencing (SLAF-seq). BMC Genom 18:1

Qin J, Shi A, Mou B, Grusak MA, Weng Y, Ravelombola W, Bhattarai G, Dong L, Yang W (2017) Genetic diversity and association mapping of mineral element concentrations in spinach leaves. BMC Genom 18:941

Rendón-Anaya M, Herrera-Estrella A (2018) The advantage of parallel selection of domestication genes to accelerate crop improvement. Genome Biol 19:147

Roberts JL, Moreau R (2016) Functional properties of spinach (Spinacia oleracea L.) phytochemicals and bioactives. Food Funct 7:3337-3353

Rolland JL, Sherman C (2006) The Food Encyclopedia: Over 8,000 ingredients, tools, techniques, and people. Robert Rose, Toronto

Rosa JT (1925) Sex expression in spinach. Hilgardia 1:259-274

Rubatzky VE, Yamaguchi M (1997) Spinach, Table Beets, and Other Vegetable Chenopods. In: Rubatzky VE, Yamaguchi M (eds) World Vegetables. Springer-Science + Business Media, Dordrecht, pp 457-465

Sabaghnia N, Asadi-Gharneh HA, Janmohammadi M (2014) Genetic diversity of spinach (Spinacia oleracea L.) landraces collected in Iran using some morphological traits. Acta Agric Slov 103:101-111

Santamaria P (2006) Nitrate in vegetables: toxicity, content, intake and EC regulation. J Sci Food Agric 86:10-17

Schouten HJ, Krauskopf J, Visser RGF, Bai Y (2014) Identification of candidate genes required for susceptibility to powdery or downy mildew in cucumber. Euphytica 200:475-486

She H, Qian W, Zhang H, Liu Z, Wang X, Wu J, Feng C, Correll JC, Xu Z (2018) Fine mapping and candidate gene screening of the downy mildew resistance gene RPF1 in Spinach. Theor Appl Genet 131:2529-2541
Sherbakoff CD (1949) Breeding for resistance to Fusarium and Verticillium wilts. Bot Rev 15:377-422

Shi A, Mou B (2016) Genetic diversity and association analysis of leafminer (Liriomyza langei) resistance in spinach (Spinacia oleracea). Genome 59:581-588

Shi A, Mou B, Correll JC, Koike ST, Motes D, Qin J, Weng Y, Yang W (2016a) Association analysis and identification of SNP markers for Stemphylium leaf spot (Stemphylium botryosum f. sp. spinacia) resistance in spinach (Spinacia oleracea). Am J Plant Sci 7:1600-1611

Shi A, Mou B, Correll JC, Motes D, Weng Y, Qin J, Yang W (2016b) SNP association analysis of resistance to Verticillium wilt (Verticillium dahliae Kleb.) in spinach. Aust $\mathbf{J}$ Crop Sci 10:1188-1196

Shi A, Mou B, Correll JC (2016c) Association analysis for oxalate concentration in spinach. Euphytica 212:17-28

Shi A, Qin J, Mou B, Correll JC, Weng Y, Brenner D, Feng C, Motes D, Yang W, Dong L, Bhattarai G, Ravelombola W (2017) Genetic diversity and population structure analysis of spinach by single-nucleotide polymorphisms identified through genotyping-by-sequencing. PLoS ONE 12: 0188745

Simoons FJ (1990) Food in China. A Cultural and Historical Inquiry. CRC Press, Boston, pp 139-140

Smith LB (1920) Breeding mosaic resistant spinach and notes on malnutrition. Bull Va Truck Exp Stat 31:137-160

Smith PG (1950) Downy mildew immunity in spinach. Phytopathology 40:65-68

Smith PG, Zahara MB (1956) New spinach immune to mildew: hybrid variety developed by plant breeding program intended for use where Viroflay is adapted, produces comparable yield. Calif Agric 10:15

Smith PG, Webb RE, Millett AM, Luhn CH (1961) Downy mildew on spinach: a second race of fungus has been found on Califlay variety in the coastal valley area of California. Calif Agric 15:5

Smith PG, Webb RE, Luhn CH (1962) Immunity to race 2 of Spinach downy mildew. Phytopathology 52:597-599

Sneep J (1983) The domestication of spinach and the breeding history of its varieties. Euphytica Supplement 2:1-27

Solberg SO, Yndgaard F, Axelsson J (2015) Nitrate and oxalate in germplasm collections of spinach and other leafy vegetables. Emirates J Food Agric 27:698-705

Soylu S, Kara M, Kurt Ş, Uysal A, Shin HD, Choi YJ, Soylu EM (2018) First report of white blister rust disease caused by Albugo occidentalis on spinach in Turkey. Plant Dis 102:826

Sun K, Wolters A-MA, Vossen JH, Rouwet ME, Loonen AEHM, Jacobsen E, Visser RGF, Bai Y (2016) Silencing of six susceptibility genes results in potato late blight resistance. Transgenic Res 25(5):731-742

Tiso M, Schechter AN (2015) Nitrate reduction to nitrite, nitric oxide and ammonia by gut bacteria under physiological conditions. PLoS ONE 10:1-18

Uotila P (1997) Chenopodiaceae. Spinacia. In: Rechinger KH (ed) Flora Iranica. Graz, ADEVA, pp 59-63

Vakalounakis DJ, Doulis AG (2013) First record of white rust, caused by Albugo occidentalis, on spinach in Greece. Plant Dis 97:1253

Van Damme M, Andel A, Huibers RP, Panstruga R, Weisbeek PJ, Van den Ackerveken G (2005) Identification of 
Arabidopsis loci required for susceptibility to the downy mildew pathogen Hyaloperonospora parasitica. Mol Plant Microbe Interact 18:583-592

Van Damme M, Huibers RP, Elberse J, Van den Ackerveken G (2008) Arabidopsis DMR6 encodes a putative 2OG-Fe(II) oxygenase that is defense-associated but required for susceptibility to downy mildew. Plant J 54:785-793

Van der Vossen HAM (2004) Spinacia oleracea. In: Grubben GJH, Denton OA (eds) Plant resources of tropical Africa 2: vegetables. Backhuys Publishers, Wageningen, pp 513-515

Van Schie CC, Takken FL (2014) Susceptibility genes 101: how to be a good host. Ann Rev Phytopathol 52:551-581

Van Treuren R, Coquin P, Lohwasser U (2012) Genetic resources collections of leafy vegetables (lettuce, spinach, chicory, artichoke, asparagus, lamb's lettuce, rhubarb and rocket salad): composition and gaps. Genet Resour Crop Evol 59:981-997

Van Treuren R, de Groot L, Hisoriev H, Khassanov F, Farzaliyev V, Melyan G, Gabrielyan I, van Soest L, Tulmans C, Courand D, de Visser J, Kimura R, Boshoven JC, Janda T, Goossens R, Verhoef M, Dijkstra J, Kik C (2019) Acquisition and regeneration of Spinacia turkestanica and $S$. tetrandra to improve a spinach gene bank collection. Genet Resour Crop Evol. https://doi.org/10.1007/s10722-01900792-8. Accessed 16 Jul 2019

Vilmorin-Andrieux (1855) Description des Plantes Potagères. Vilmorin Andrieux \& Cie, Paris, pp 127-130. https:// gallica.bnf.fr/ark:/12148/bpt6k10250876/f5.item. Accessed 6 Mar 2019

Vilmorin-Andrieux (1883) Les Plantes Potagères. Vilmorin Andrieux \& Cie, Paris, pp 202-206. https://gallica.bnf.fr/ ark:/12148/bpt6k9641303z/f9.image.texteImage. Accessed 6 Mar 2019

Vincent H, Wiersema J, Kell S, Fielder H, Dobbie S, CastañedaÁlvarez NP, Guarina L, Eastwood R, León B, Maxted N (2013) A prioritized crop wild relative inventory to help underpin global food security. Biol Cons 167:265-275. https://www.cwrdiversity.org/checklist/. Accessed 14 May 2019

Wang M, Li W, Fang C, Xu F, Liu Y, Wang Z, Yang R, Zhang M, Liu S, Lu S, Lin T, Tang J, Wang Y, Wang H, Lin H, Zhu B, Chen M, Kong F, Liu B, Zeng D, Jackson SA, Chu C, Tian Z (2018a) Parallel selection on a dormancy gene during domestication of crops from multiple families. Nat Genet 50:1435-1441

Wang X, Cai X, Xu C, Zhao Q, Ge C, Dai S, Wang Q-H (2018b) Diversity of nitrate, oxalate, vitamin $\mathrm{C}$ and carotenoid contents in different spinach accessions and their correlation with various morphological traits. J Hortic Sci Biotechnol 93:409-415

Weretilnyk EA, Hanson A (1988) Betaine aldehyde dehydrogenase polymorphism in spinach: genetic and biochemical characterization. Biochem Genet 26:143-151

Witcombe JR, Hollington PA, Howarth CJ, Reader S, Steele KA (2008) Breeding for abiotic stresses for sustainable agriculture. Philos Trans R Soc B Biol Sci 363:703-716

Xu C, Jiao C, Sun H, Cai X, Wang X, Ge C, Zheng Y, Liu W, Sun X, Xu Y, Deng J, Zhang Z, Huang S, Dai S, Mou B, Wang Q, Fei Z, Wang Q (2017) Draft genome of spinach and transcriptome diversity of 120 Spinacia accessions. Nat Commun 8:1-10

Yamamoto K, Oda Y, Haseda A, Fujito S, Mikami T, Onodera Y (2014) Molecular evidence that the genes for dioecism and monoecism in Spinacia oleracea L. are located at different loci in a chromosomal region. Heredity 112:317-324

Zink FW, Smith PG (1958) A second physiological race of spinach downy mildew. Plant Dis 42:818

Zuccarini P, Savé R (2016) Three species of arbuscular mycorrhizal fungi confer different levels of resistance to water stress in Spinacia oleracea L. Plant Biosyst 150:851-854

Publisher's Note Springer Nature remains neutral with regard to jurisdictional claims in published maps and institutional affiliations. 